\title{
4. SEISMIC REFLECTION SITE SURVEY: CORRELATION WITH PHYSICAL PROPERTIES, LEG 91, DEEP SEA DRILLING PROJECT ${ }^{1}$
}

\author{
Isaac I. Kim, Deborah K. Smith, H. William Menard², John A. Orcutt, and Thomas H. Jordan, \\ Scripps Institution of Oceanography ${ }^{3}$
}

\begin{abstract}
Seismic-reflection data collected for the site survey of Leg 91 of the Deep Sea Drilling Project (DSDP) are described. Correlations of these reflection data with physical-properties measurements from the recovered cores are discussed. The predicted "reverberant layer" (Houtz and Ludwig, 1979) was not found. Synthetic seismograms indicate the "reverberant layer's" presence in earlier reflection data is due to narrow-band analog recording techniques.
\end{abstract}

\section{INTRODUCTION}

Leg 91 of the Deep Sea Drilling Project (DSDP) deployed and recovered the Defense Advanced Research Project Agency's (DARPA) Marine Seismic System (MSS). An attempt to deploy the MSS during Leg 88 off Kamchatka was aborted because of drilling difficulties in a high sea state. The MSS featured a borehole instrument package (BIP), which was emplaced beneath pelagic sediments $70 \mathrm{~m}$ into the oceanic crust by the Glomar Challenger. Earthquakes, refraction shots, and microseismic noise were recorded by a triaxial seismometer and hydrophone located in the BIP, as well as by an ocean bottom seismometer (OBS) array surrounding the drilling site. The primary scientific objective of Leg 91, referred to as the Ngendei Expedition, was to compare the instrument response of these downhole seismometers to the OBSs and to determine how much improvement in the signal-to-noise ratio would be obtained by placing a seismometer beneath ocean sediments in a supposedly quieter environment (Adair et al., and Shearer et al., this volume). The site survey for Leg 91 was performed by the Melville of the Scripps Institution of Oceanography (SIO) and included magnetics, $12-\mathrm{kHz}$ bathymetry, and $3.5-\mathrm{kHz}$ profiling and digital water-gun seismic-reflection profiling.

\section{PRELIMINARY SITE SELECTION}

The drilling site was located at a latitude of $24^{\circ} \mathrm{S}$, 1000 kilometers east of the Tonga Trench (see Fig. 1, designated MSST-5). The site was chosen because of its proximity to the Tonga-Kermadec Trench, the most seismically active area in the world (Oliver and Isacks, 1967; Isacks et al., 1968).

\footnotetext{
${ }^{1}$ Menard, H. W., Natland, J., Jordan, T. H., Orcutt, J. A., et al., Init. Repts. DSDP, 91: Washington (U.S. Govt. Printing Office).

2 Deceased.

3 Addresses: (Kim, Orcutt) Institute of Geophysics and Planetary Physics (A-025), Scripps Institution of Oceanography, La Jolla, CA 92093; (Smith, present address) Woods Hole Oceanographic Institution, Woods Hole, MA 02543; (Menard) Institute of Marine Resources, Geological Research Division, Scripps Institution of Oceanography, La Jolla, CA 92093; (Jordan, present address) Department of Earth, Atmospheric, and Planetary Sciences, Massachusetts Institute of Oceanography, Cambridge, MA 02139
}

Little is known about the tectonic history of this portion of the South Pacific, since there are only a few widely spaced shiptracks through the area. From hot-spot traces, we can assume that this crust was produced from a fast-spreading ridge at a high southern latitude in the Early Cretaceous. This would place the site's origin somewhere in the center of the Mesozoic world ocean (presentday Pacific) when the Atlantic started its present-day opening phase. As this portion of oceanic crust migrated across the Pacific, it was far removed from any source of continental sediments and never passed under the highly productive equatorial zone. Therefore, even though this oceanic crust is quite old, we anticipated and found a very thin sediment cover.

Engineering constraints required that the site be located in water less than $5500 \mathrm{~m}$ deep and have at least $100 \mathrm{~m}$ of sediment for lateral support of the bottomhole assembly. Seismic-reflection profiles from the 1969 Eltanin and 1972 Conrad expeditions were used to pick a primary target (MSST-5 in Fig. 1) and an alterate site (MSST-3 in Fig. 1). Two sites (SS-1 and SS-2 in Fig. 1) were also chosen at a lower latitude in case of inclement weather at the primary target. The Melville was to survey the primary target area in detail with its digital water-gun reflection system to locate a site sufficiently shallow in depth and with thick enough sediments to satisfy the drilling requirements.

Underway geophysical data were acquired by the Glomar Challenger and Melville during transits both to and from the site. Most of the surveying at the site, however, was performed by Melville.

\section{CHALLENGER UNDERWAY DATA COLLECTION}

Depth, magnetic, and water-gun profiles were recorded during the transit of Glomar Challenger from New Zealand to the proposed drill site. The shiptrack of Glomar Challenger during Leg 91 is shown in Figure 2. After leaving Wellington, an abrupt increase in seafloor depth indicated that Challenger had crossed the limit of the New Zealand continental crust. A 700-m scarp (see Fig. 3) descended to a region with depths commonly as great as $5400-5800 \mathrm{~m}$. In this region, bounded to the north by the Louisville Ridge, Glomar Challenger crossed a group 


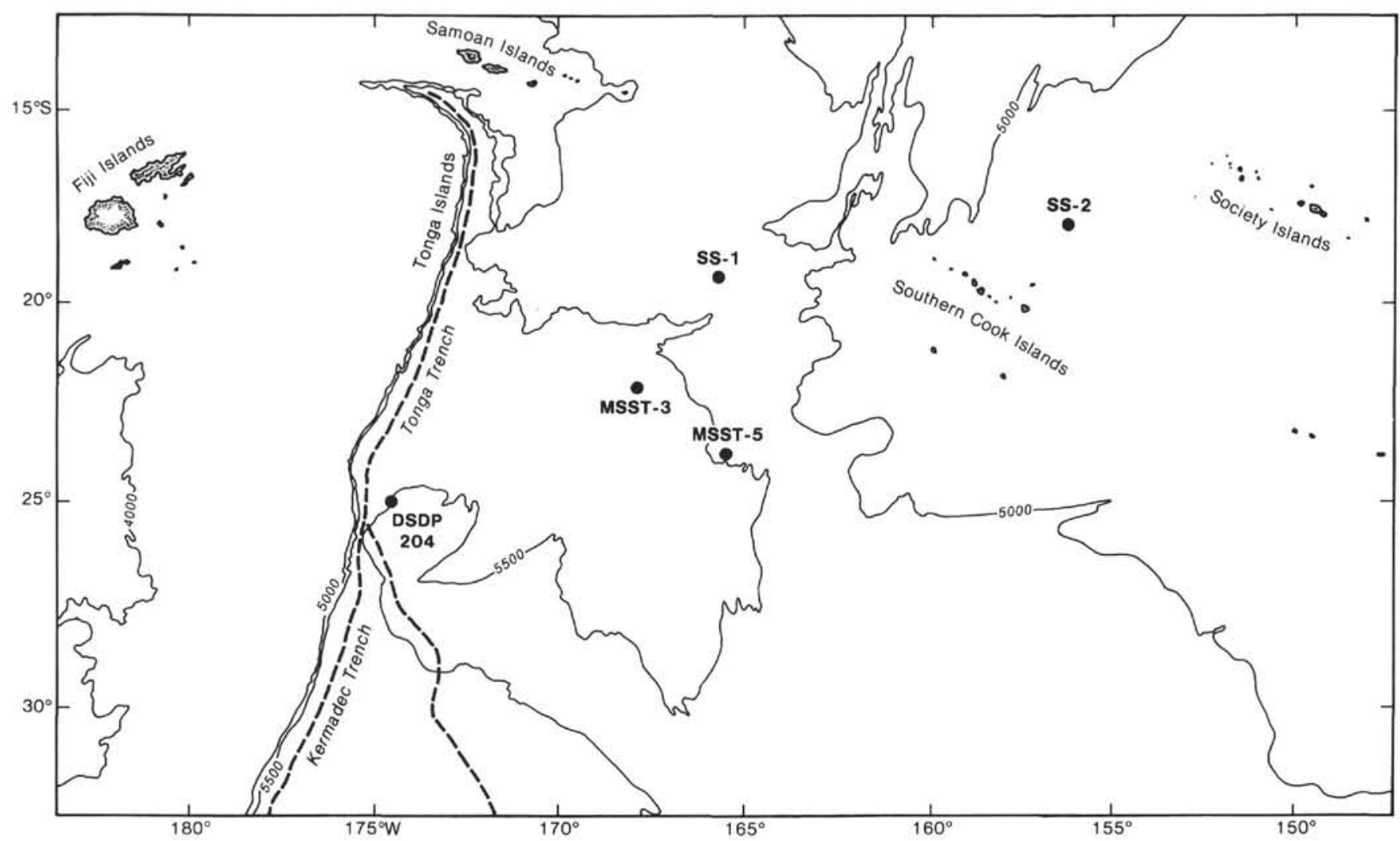

Figure 1. Location of preliminary site survey areas MSST-5 (primary) and MSST-3 (alternative), contingency "storm" sites SS-1 and SS-2, and DSDP Site 204 in the southwest Pacific. A suitable site for Leg 91 was found at MSST-5.

of highs and lows with relief as great as $1000 \mathrm{~m}$. This relief is partly concealed by as much as $500 \mathrm{~m}$ of sediment in the lows. Bathymetric trends in this region appear on bathymetric maps (Mammerickx et al., 1975) and are interpreted to be approximately parallel to the trend of the Louisville Ridge (See Fig. 1).

Glomar Challenger's track across the Louisville Ridge was chosen to supplement tracklines of previous expeditions. In this area, bathymetric maps (Mammerickx et al., 1975) show an elongate, sinuous ridge, but Challenger's sounding line (see Fig. 4) in conjunction with a sounding line by Eltanin indicates that the ridge at this point is probably a circular volcano instead of a local high on an elongate ridge.

From the Louisville Ridge to the proposed drill site, the ship sailed on course to confirm the existence of a narrow trough trending southwest-northeast and reaching a basement depth of nearly $6950 \mathrm{~m}$. Glomar Challenger verified the existence and southwesterly trend of this trough. The along-track morphology shows two asymmetric ridges separated by a deep trough reaching a basement depth of $6000 \mathrm{~m}$, far below common regional depths of about $5500 \mathrm{~m}$ (see Fig. 5) and indicates a probable deepening of the trough to the southwest.

As seen from Glomar Challenger, relief of the seafloor near the drill site is low, less than $150 \mathrm{~m}$, and digital water-gun records indicate a sediment thickness of approximately $30 \mathrm{~m}$. Drilling results demonstrated that, in fact, the sediments were 70 meters in thickness. $\mathrm{Mel}$ ville's seismic profiles subsequently showed that, because of high-pass filtering, Glomar Challenger was recording only the water-gun pulse reflecting off the top of thin chert and porcellanite stringers. Lower frequency energy penetrating the total sediment thickness was not recorded.

Glomar Challenger left the drill site on 16 February for Papeete, Tahiti, with a transit course through the Cook Island chain. Numerous seamounts and guyots were crossed during the transit.

\section{MELVILLE SITE SURVEY}

Melville left Honolulu on 9 January 1983, 1 week before Glomar Challenger left Wellington. After 11 days of transit, Melville arrived at the proposed site $36 \mathrm{hr}$. before the arrival of Glomar Challenger.

The seismic source used by Melville was an $80-$ in $^{3}$ water gun, operated at 1800 psi. A water gun is a high-frequency implosive source that does not generate a bubble pulse and thus reverberates much less than a conventional air gun (French and Henson, 1978; Hutcheson and Detrick, 1984). The single-channel receiver streamer consisted of 50 hydrophones, spaced at 1-m intervals, towed $275 \mathrm{~m}$ behind the Melville. The reflection data were recorded digitally at a sampling interval of $2 \mathrm{~ms}$ on an IBM 1800 with band-pass filters set at 15 to $125 \mathrm{~Hz}$, and displayed in real time on a Tektronix screen. Real-time processed (automatic gain control, trace equalization) reflection profiles were used by the Melville scientists to determine the final drilling site. Altogether, $500 \mathrm{~km}$ of digital seismic-reflection data were collected. The reflection site survey shiptrack, along with the surveyed ba- 


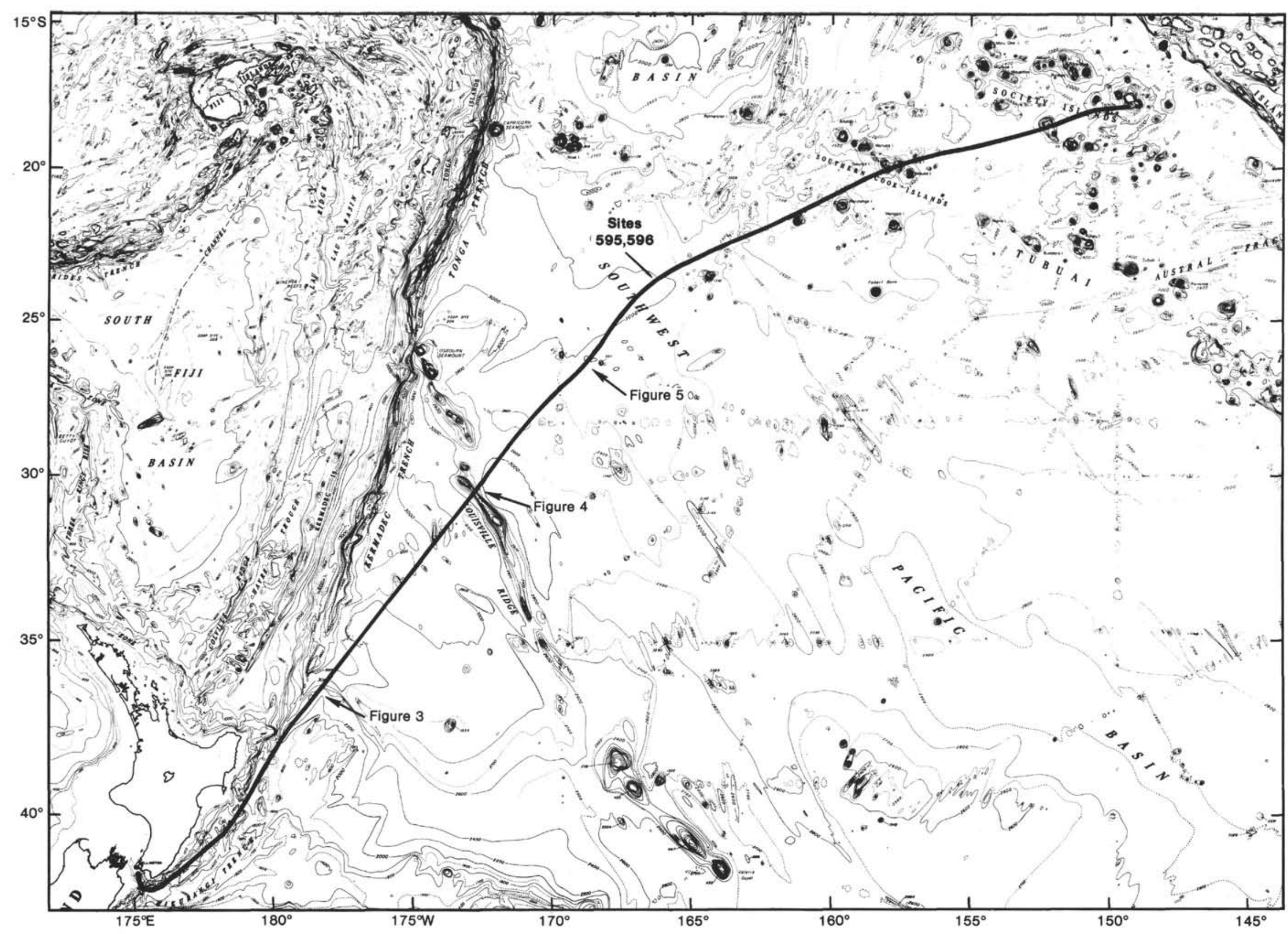

Figure 2. Glomar Challenger's shiptrack during Leg 91 . It left Wellington, New Zealand on 15 January 1983 arriving at the site on 22 January. Glomar Challenger left the site on 16 February and arrived in Papeete, Tahiti on 20 February. The locations of Figures 3, 4, and 5 are indicated on the shiptrack (base map from Mammerickx et al., 1975). 


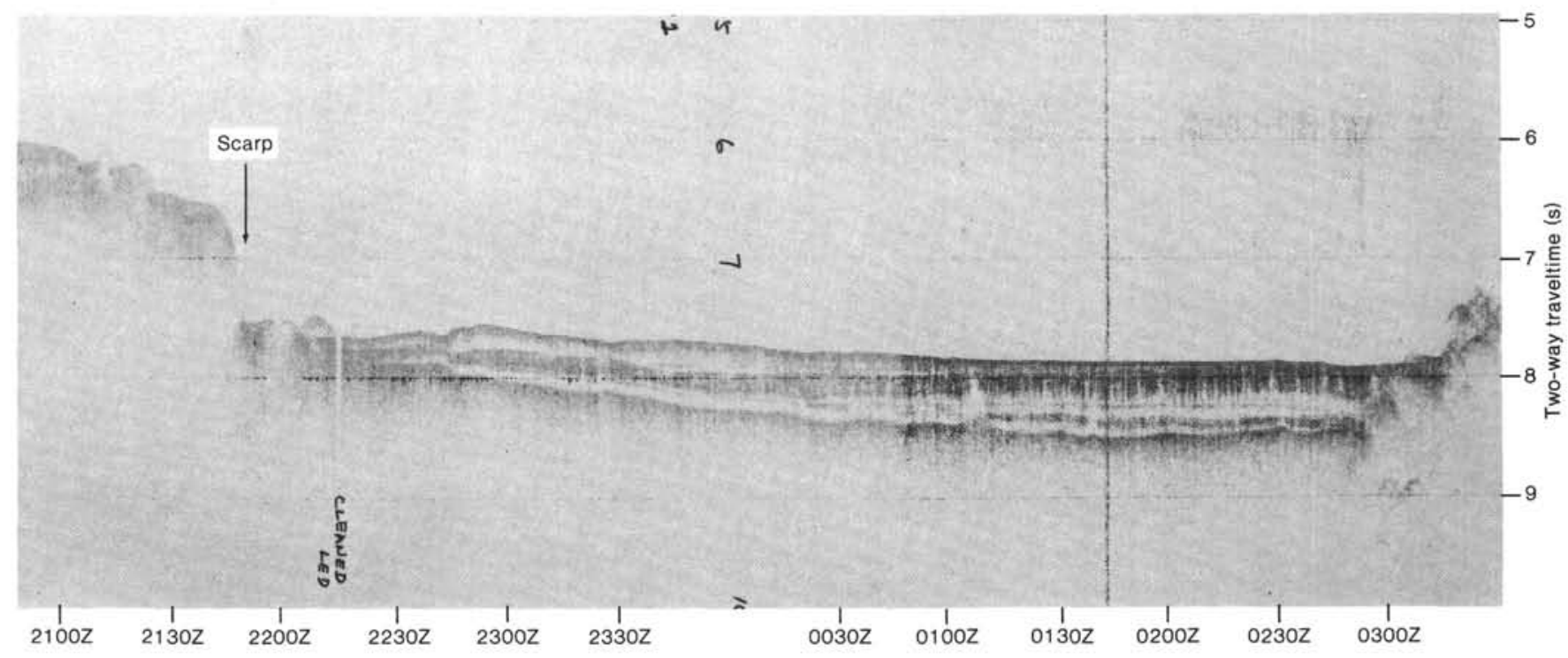

Figure 3. Air-gun record of Glomar Challenger as it leaves the New Zealand shelf. Exact location of the edge of the shelf is indicated by the 700-m scarp.

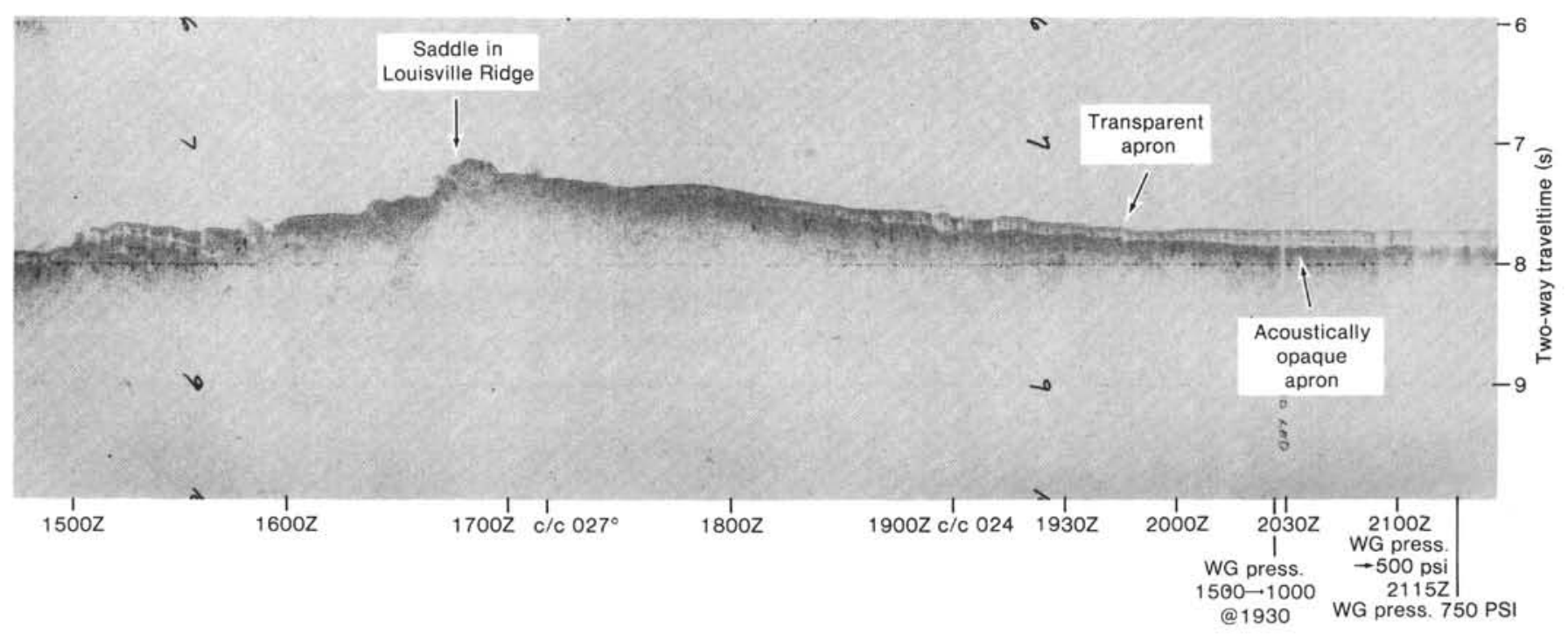

Figure 4. Glomar Challenger's air-gun record as it passes over the Louisville Ridge.

thymetry, is shown in Figure 6. Details of the individual site survey lines are shown in Figures 7, 20, and 30.

The site survey was broken into eight lines and these are displayed in Figures 8-32. These profiles have been reprocessed at Scripps using a partial deconvolution. A water-gun source function is not minimum phase because of a low-frequency precursor. This phase behavior precludes the use of a conventional spiking deconvolution algorithm (Robinson and Treitel, 1980). The partial deconvolution prewhitened the amplitude spectrum but did not alter the phase spectrum. We found this process did very little to change the appearance of the seismic data and only marginally increased the frequency content. In the future, water-gun source functions digitized on board ship at a sampling interval of $20 \mu \mathrm{s}$ will be used to obtain spectral estimates of the water-gun source. These estimates will allow a deterministic deconvolution to be applied to these data in order to increase the spectral resolution and thus improve the stratigraphic interpretation. Migration of these seismic profiles would collapse strong hyperbolas noticeable on some of the basement reflections, but would do little to improve the stratigraphic interpretation since most of these reflections are nearly horizontal. The locations of site survey reflection Lines 1, 2, and 3 are shown in Figure 7.

\section{Line 1 (20 Jan./17:40Z-21 Jan./2:30Z) (Figs. 8-13)}

This was a long $\mathrm{N}-\mathrm{S}$ line, the first running through the proposed initial survey area. Two areas along this line were considered:

Area A: 1800Z-1925Z (see Fig. 8): The sediment reflections look very flat and undisturbed. 


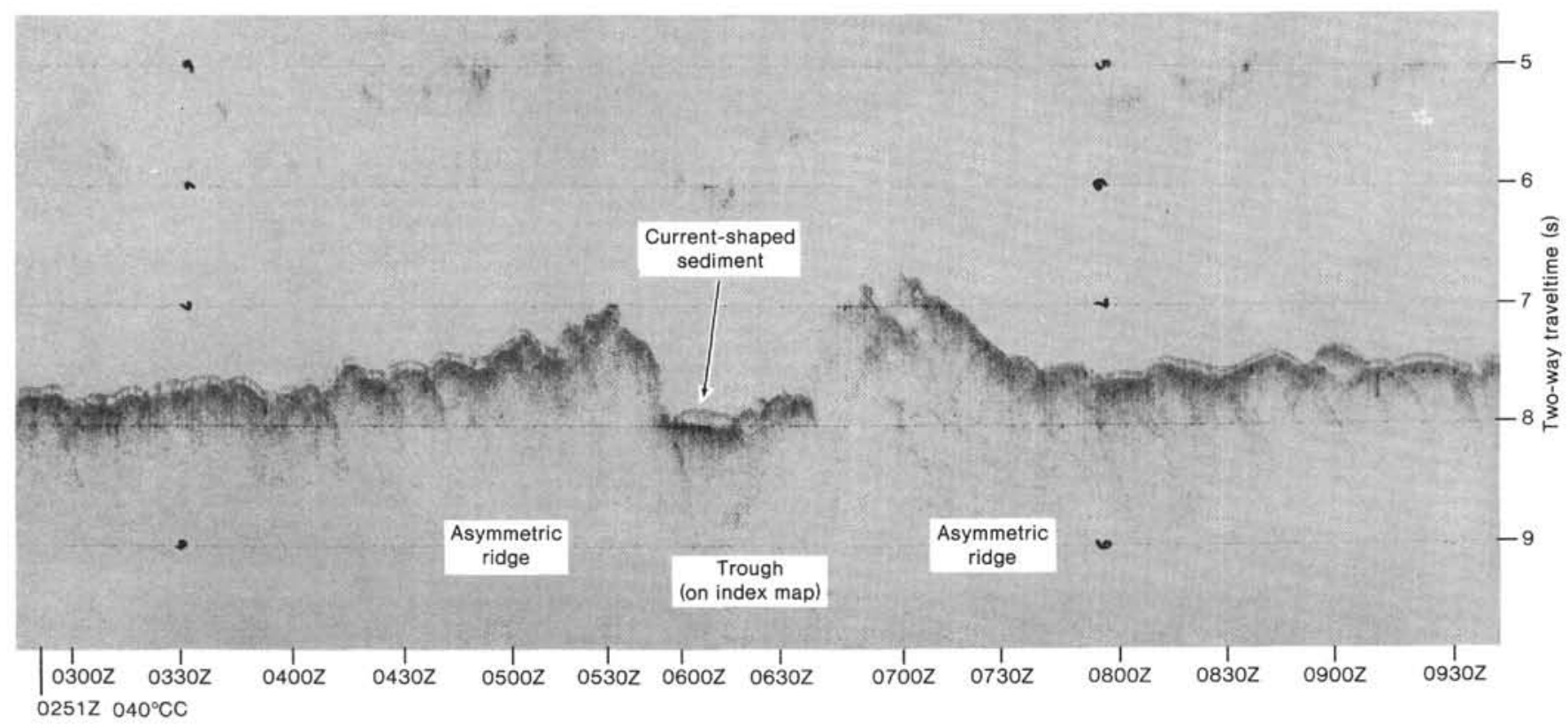

Figure 5. Glomar Challenger's air-gun record as it passes over a deep trough on the way to the site.

Area B. 2100Z-0045Z (see Fig. 10): The sediment reflections are poorer, but there is less large-scale topography in the vicinity.

At both sites, the water depth was about $5625 \mathrm{~m}$; $125 \mathrm{~m}$ deeper than our target depth. The sediment thickness at both sites was about $90 \mathrm{~m}$. This estimate was based on a two-way traveltime of $0.12 \mathrm{~s}$ from the first arrival to what appeared to be the basement reflector (chosen on the strength of that reflector and the lack of any clear reflections below it). However, since the first arrival was picked at the start of the water-gun wavelet and because of the error in picking exactly where in the broad wavelet the actual basement lies, the sediment thickness estimate represents an upper bound. It was decided to survey Area B in greater detail since the lack of topography would benefit the interpretation of the seismic refraction data. Indications of rough topography around Area A include the deep hyperbola at $1945 \mathrm{Z}$ at about $8.1 \mathrm{~s}$ (see Fig. 9). This is most likely an out-ofplane reflection, since it is found below the basement reflector.

\section{Line 2 (21 Jan./2:30Z-21 Jan./7:45Z) (Figs. 14-16)}

After completing Line 1, we maneuvered the ship to obtain a perpendicular crossing through Line 1 at Area B. The sediments seemed to be about the same thickness as previously observed in Line 1 with the same bumpy, uneven basement reflection. The strong hyperbolas along the basement reflection are most likely from small faults in the upper part of the basalt. Again, migration would collapse these hyperbolas and concentrate the scattered energy at the apex of the hyperbola, making the basement reflector much stronger. We passed a large topographic feature which was not recorded in the seismic data because the delay switches were not adjusted correctly (see Fig. 15). All the sedi- ments appeared to be very flat, indicating a pelagic source.

Line 3 (21 Jan./7:45Z-21 Jan./11:45Z) (Figs. 17-19)

This is the W-E cross line through Area B. Other than the bathymetric high at $0815 \mathrm{Z}$ (see Fig. 17), the topography was relatively flat. The sediments seemed to thicken and thin slightly as the basement reflector moved slowly up and down. Again, we saw many hyperbolas in the top of the basalt reflection, indicating a rough basement. There appeared to be a thick mound of sediments at $1055 \mathrm{Z}$ (see Fig. 19); Line 1 passed near this mound, yet no such feature was seen on Line 1 . This was most likely because of errors in navigation. This region near the mound exhibited the thickest observed sediments, but these thick sediments were very localized.

The locations of site survey reflection Lines 4,5 , and 6 are shown in Figure 20.

Line 4 (21 Jan./11:45Z-21 Jan./15:15Z) (Figs. 21-22)

This portion of the survey was run to determine if the sediments thickened south of Line 3. The line ran south slightly and then east, crossing Line 1 . The sediments were of the same thickness although the sediment reflections looked a little flatter and less disturbed than the sediment reflections on Line 3. However, the surrounding topography seemed to be rougher, as indicated by the exceptional out-of-plane reflection at $8.5 \mathrm{~s}$ (see Fig. 22).

Line 5 (21 Jan./15:15Z-21 Jan./19:15Z) (Figs. 23-25)

The ship was steered back through Area B in a NW direction for one final check. Again, the mound was evident (see Fig. 24). Glomar Challenger arrived in the area and recorded a much thinner sediment thickness. The discrepancy between the observations was explained by differences in the recording settings used on the two 


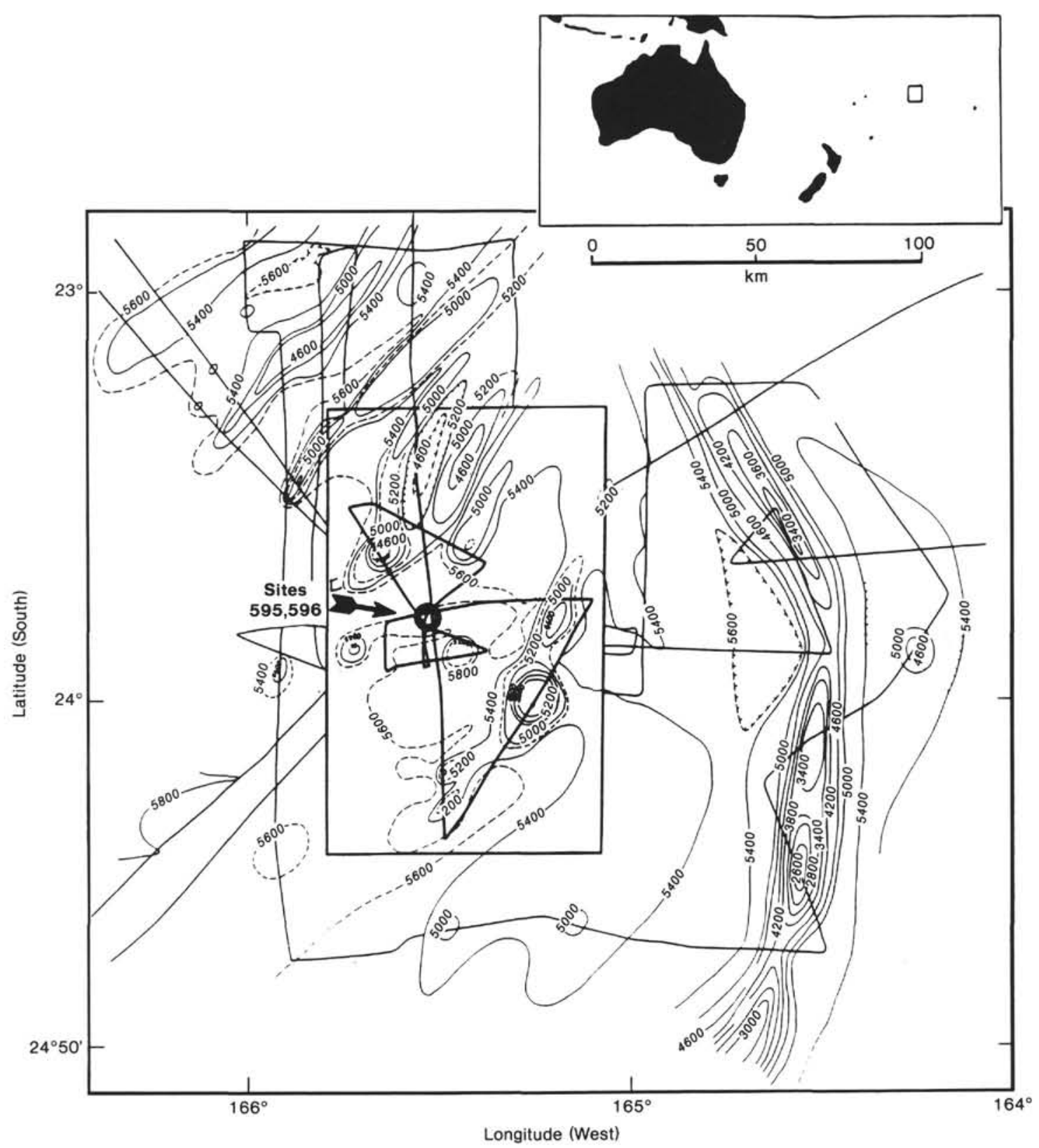

Figure 6. Bathymetry (in meters) around DSDP Sites 595 and 596 along with Melville's shiptrack. Boxed in area indicates the extent of the water-gun reflection survey. Five hundred kilometers of digital seismic-reflection data were collected along the darker line within the box.

ships: Both ships were using a water gun as their seismic source but Melville used a greater bandwidth, which extended the signals to lower frequencies and yielded greater penetration. During the actual drilling, cherts were encountered about midway through the sediments. A high reflection coefficient existed between the hard cherts and the soft overlying pelagic sediments. Glomar Challenger recorded the chert reflection as acoustic basement, since its filters were set to record much higher frequencies. Glomar Challenger passed over the chosen site and dropped the positioning beacon at $1700 \mathrm{Z}$ for the first exploratory hole (595), in the vicinity of the sediment mound seen in Line 3 .
Line 6 (21 Jan./19:15Z-22 Jan./1:00Z) (Figs. 26-29)

Melville surveyed north of Area B during the early drilling operations and encountered rougher topography (Fig. 27). As the ship returned to the site, the sediments thickened slightly. During the drilling of Hole 595, the expedition Chief Scientists met on Glomar Challenger with copies of the seismic profiles to discuss the site and examine the initial cores. These results showed that the sediments were soft and perhaps too thin. Apparently, Glomar Challenger was drilling at the peak of the mound seen on the seismic data-where the sediments appeared to be thinnest. Line 3 indicated thicker sediments just 


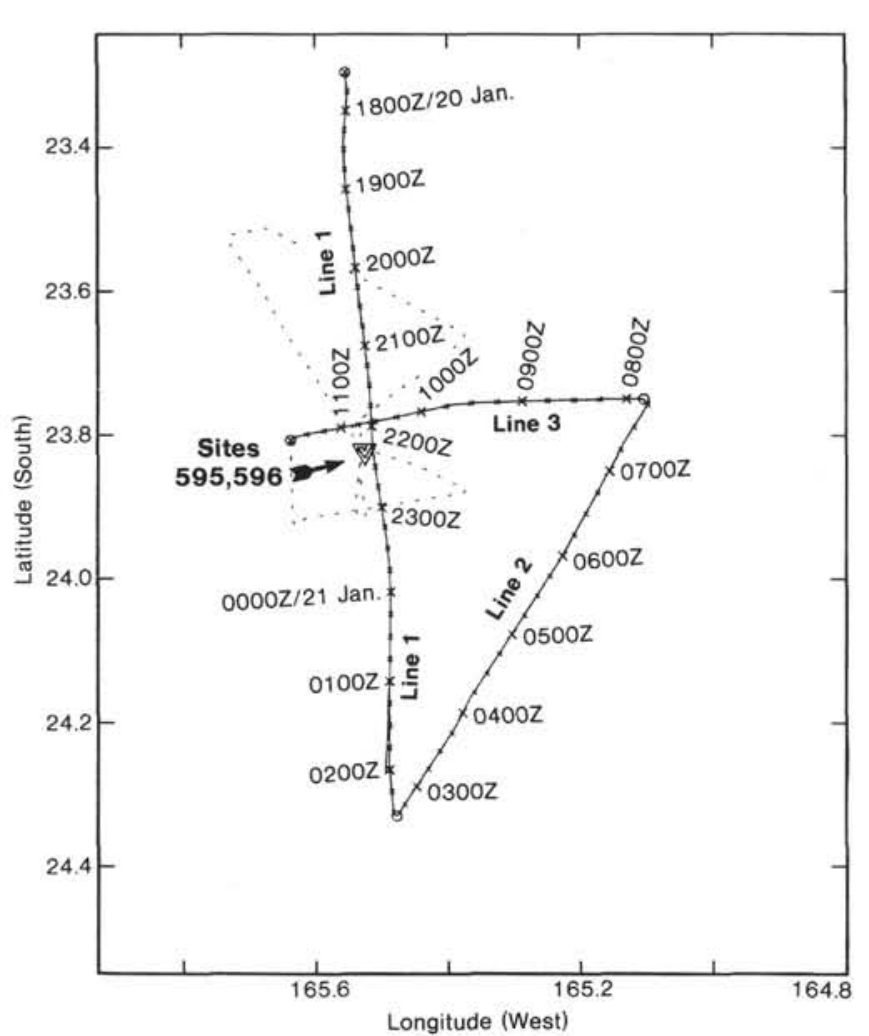

Figure 7. Location of site survey reflection Lines 1-3. Filled triangle indicates the location of the chosen drill site. The remainder of the survey is shown by the dashed lines.

off the mound and slightly to the east (see Fig. 19); this accumulation could be attributed to sediment slumping from the mound. Glomar Challenger moved $460 \mathrm{~m}$ east to drill the second exploratory hole (595A), while Melville continued to survey, now to the south.

The locations of site survey reflection Lines 7 and 8 are shown in Figure 30.

\section{Line 7 (22 Jan./7:00Z-22 Jan./8:45Z) (Fig. 31)}

The Melville survey to the south, conducted during the drilling of Hole 595A, failed to find any evidence of increased sediment thickness which was thought to be necessary for setting a reentry cone. Melville returned to Area B.

\section{Line 8 (22 Jan./8:45Z-22 Jan./10:45Z) (Fig. 32)}

During this survey leg, which extended north to Glomar Challenger, it was decided that the present site was the best available within the site survey area. Drilling operations continued even though results from the second exploratory hole indicated only $70 \mathrm{~m}$ of sediments. While Glomar Challenger started to drill reentry Hole 595B (location: $23^{\circ} 49^{\prime} \mathrm{S}, 165^{\circ} 32^{\prime} \mathrm{W}$ ), Melville moved off to deploy the OBSs for the initial teleseismic recording experiment.

The bathymetric survey using the $12-\mathrm{kHz}$ and the $3.5-$ $\mathrm{kHz}$ echosounders continued as Glomar Challenger drilled Hole 595B and deployed the BIP. From the orientation of a series of ridges northwest of the site, the direction of spreading at the time of crustal formation was estimated to be N45W (see Fig. 6). Subsequent analysis of the refraction data failed to confirm this hypothesis (Shearer et al., this volume).

\section{CORRELATION WITH PHYSICAL PROPERTIES}

Lithologic analysis and physical measurements of the cored sediments from Holes 595 and 596 (see site chapters, this volume) revealed two major stratigraphic units (Fig. 33). The first $40 \mathrm{~m}$ consisted of a homogeneous layer of zeolitic pelagic clays. There was a high percentage of recovery in this unit and all measurements of physical properties were very consistent. Sonic velocities measured at $400 \mathrm{kHz}$ with a Hamilton Frame Velocimeter varied only slightly from $1.5 \mathrm{~km} / \mathrm{s}$ in the pelagic clays. Wet-bulk density measurements using a Gamma Ray Attenuation Porosity Evaluator (GRAPE) averaged 1.29 $\mathrm{Mg} / \mathrm{m}^{3}$. Below $40 \mathrm{~m}$, the dominant sediment was still pelagic clay, but thin stringers $(<10 \mathrm{~m}$ thick) of porcellanite and chert were encountered. Core recovery in this unit was very poor because of the difficulty in drilling through the very hard stringers. Only one sample of chert recovered was large enough for physical properties measurements. This sample gave a much higher sonic velocity of $3.8 \mathrm{~km} / \mathrm{s}$ and a wet-bulk density of $2.46 \mathrm{Mg} / \mathrm{m}^{3}$. A thin layer of metalliferous sediments was encountered immediately above the basalts but no physical properties measurements were taken. Basalt samples tested exhibited a mean sonic velocity of $4.7 \mathrm{~km} / \mathrm{s}$. Lower velocities seemed to be associated with veined basalt cores and higher velocities associated with massive, uncracked, and unveined basalts. The GRAPE wet-bulk density measurements in the basalts averaged $2.70 \mathrm{Mg} / \mathrm{m}^{3}$.

A comparison of downhole lithology and physical properties with water gun and $3.5-\mathrm{kHz}$ reflection data recorded near the site by Melville is shown in Figure 33. Different reflections are seen in the two profiles because of the resolution of the different recording systems.

The water-gun data show a strong basement reflection from the top of the basalt layer. However, no strong reflection is seen where the interbedded cherts begin, even though a large velocity contrast and thus a large reflection coefficient exists between the cherts and the surrounding pelagic clays. This lack of a strong chert reflection resulted from the chosen frequencies recorded by Melville's digital reflection system, which extended from 15 to $125 \mathrm{~Hz}$. These lower frequencies are characterized by wavelengths too long to resolve the thin layering. However, a strong reflection corresponding to the top of the interbedded chert layer is seen in the $3.5-\mathrm{kHz}$ data.

A $3.5-\mathrm{kHz}$ profile near the drill site is shown on the right in Figure 33. The two-way traveltime between the first reflection from the bottom and the only other strong reflector in the $3.5-\mathrm{kHz}$ record is $0.05 \mathrm{~s}$. This corresponds to a depth of $38 \mathrm{~m}$ if a velocity of $1.5 \mathrm{~km} / \mathrm{s}$ is used. This depth is far too shallow for this strong reflection to correspond to the top of the basalts. Because the wavelength of the $3.5-\mathrm{kHz}$ source is $0.4 \mathrm{~m}$ (compared to $30 \mathrm{~m}$ for the water-gun wavelength), a thin 10 -m stringer of cherts 
$s$

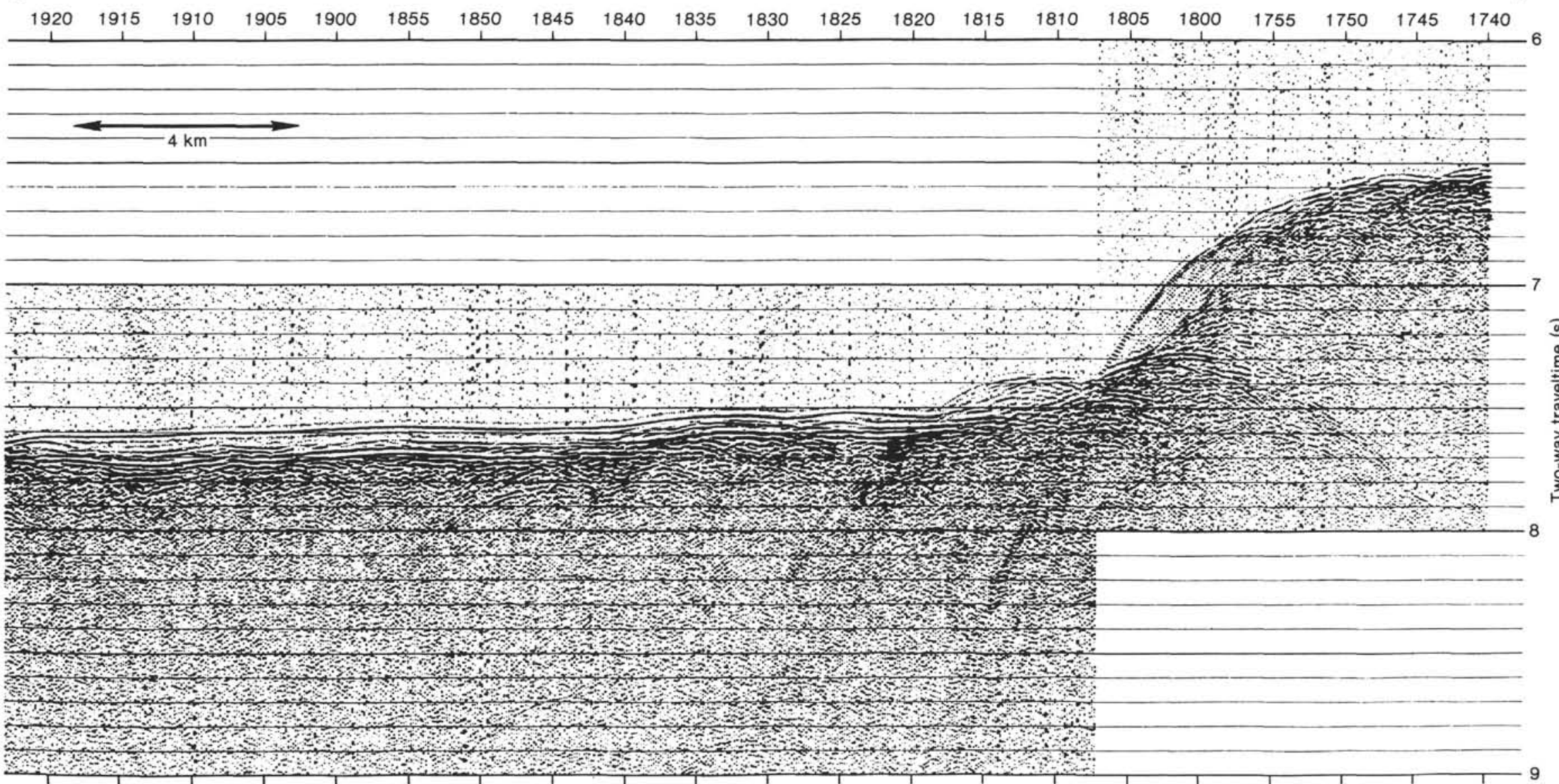

Figure 8. The beginning of Line 1 of Leg 91's water-gun reflection site survey. Two-way traveltime is displayed in the margin. The first site considered lies between $1820 \mathrm{Z}$ and $1920 \mathrm{Z}$. 
S

\begin{tabular}{|c|c|c|c|c|c|c|c|c|c|c|c|c|c|c|c|c|c|c|c|c|}
\hline $\begin{array}{c}2100 \\
1\end{array}$ & $\begin{array}{r}2055 \\
1 \\
\end{array}$ & $\begin{array}{r}205 \\
1\end{array}$ & $\begin{array}{r}204 \\
1\end{array}$ & $\begin{array}{r}204 \\
1\end{array}$ & $\begin{array}{r}2035 \\
1 \\
\end{array}$ & $\begin{array}{r}2030 \\
1 \\
\end{array}$ & $\begin{array}{r}202 \\
1\end{array}$ & $\begin{array}{r}202 \\
1\end{array}$ & $\begin{array}{r}201 \\
1 \\
\end{array}$ & $\begin{array}{r}201 \\
1\end{array}$ & $\begin{array}{r}200 \\
1\end{array}$ & $\begin{array}{r}200 \\
1\end{array}$ & $\begin{array}{r}195 \\
1 \\
\end{array}$ & $\begin{array}{r}1950 \\
\end{array}$ & $\begin{array}{r}194 \\
1 \\
\end{array}$ & $\begin{array}{r}1940 \\
\end{array}$ & $\begin{array}{r}193 \\
\end{array}$ & $\begin{array}{r}1930 \\
\end{array}$ & $\begin{array}{r}1925 \\
\end{array}$ & $\begin{array}{r}1920 \\
\perp \\
\end{array}$ \\
\hline
\end{tabular}

$\longrightarrow$

\begin{tabular}{l}
\hline$-1-1$ \\
\hline
\end{tabular}

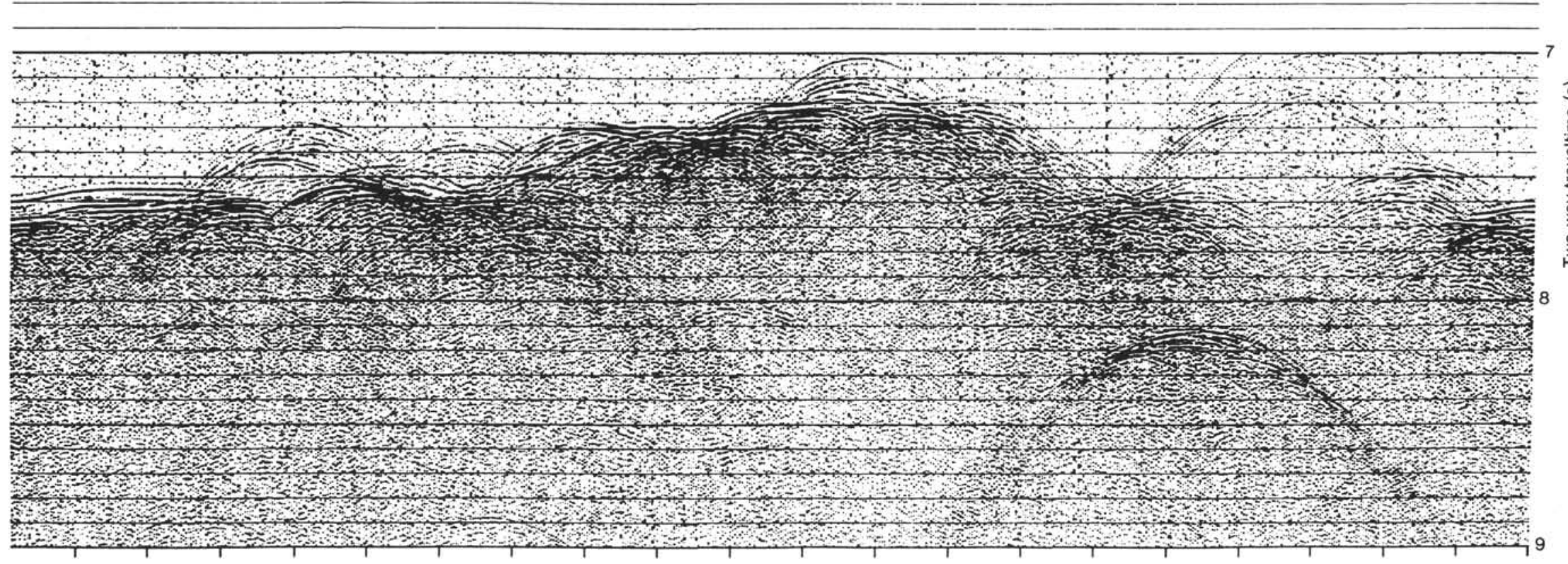

Figure 9. Line 1 (continued). Here the bathymetry has become much rougher, especially noticeable by the out-of-plane reflection at $1940 \mathrm{Z}$ at $8.2 \mathrm{~s}$. 


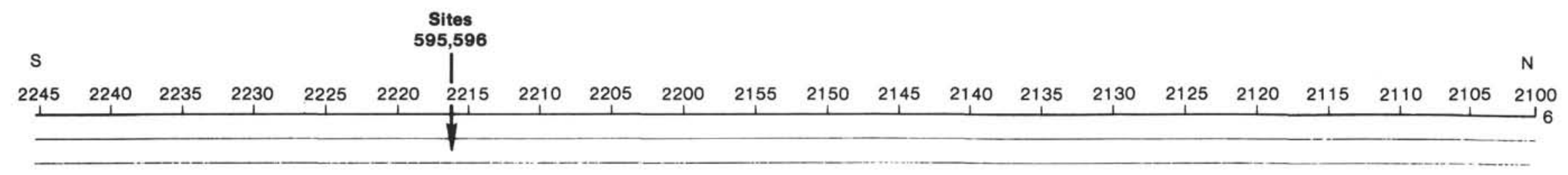
$+6$

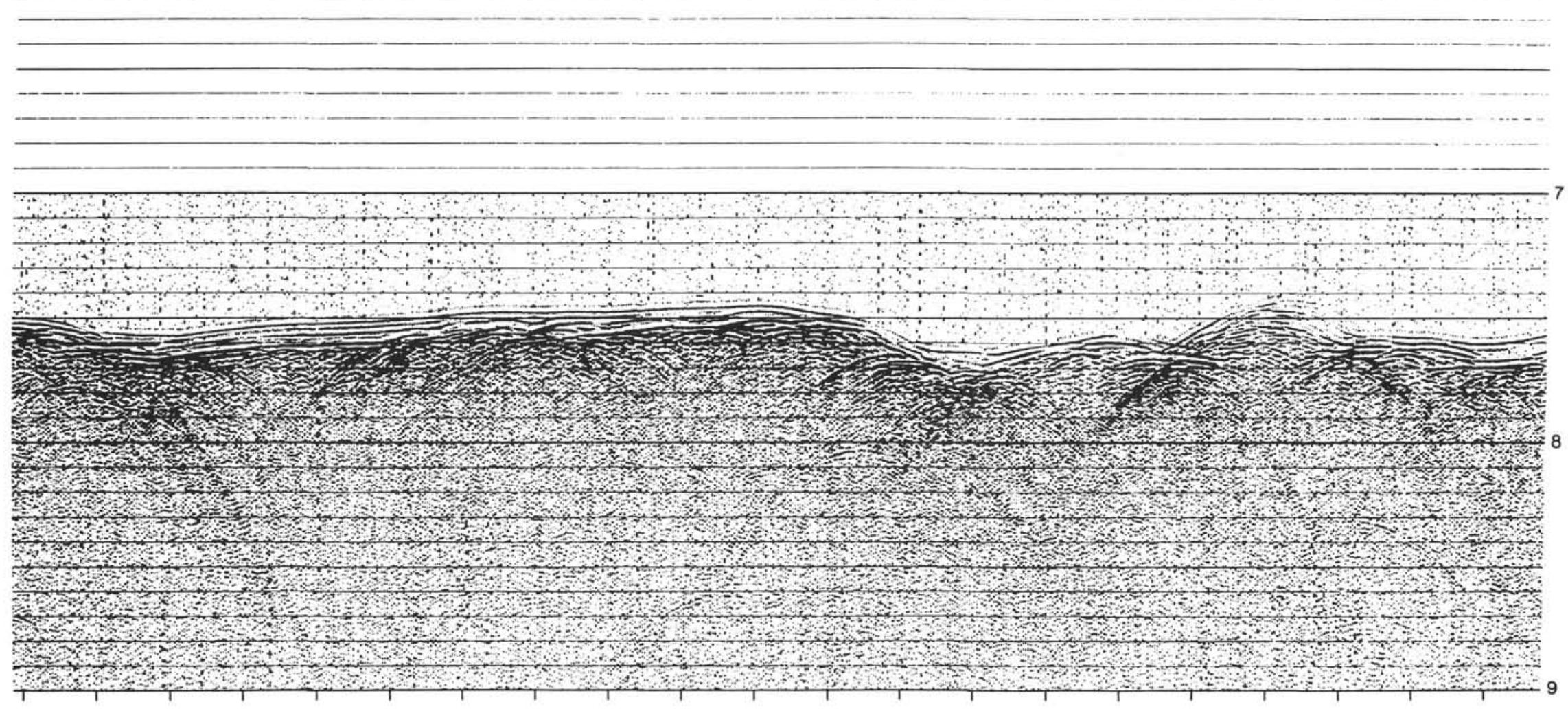

Figure 10. Line 1 (continued). This profile shows the second site considered. The actual drilling site is indicated by the arrow. The sediment thickness at the site was estimated at $90 \mathrm{~m}$ using a sediment velocity of $1500 \mathrm{~m} / \mathrm{s}$. Sediment thickness obtained by drilling was $70 \mathrm{~m}$. 


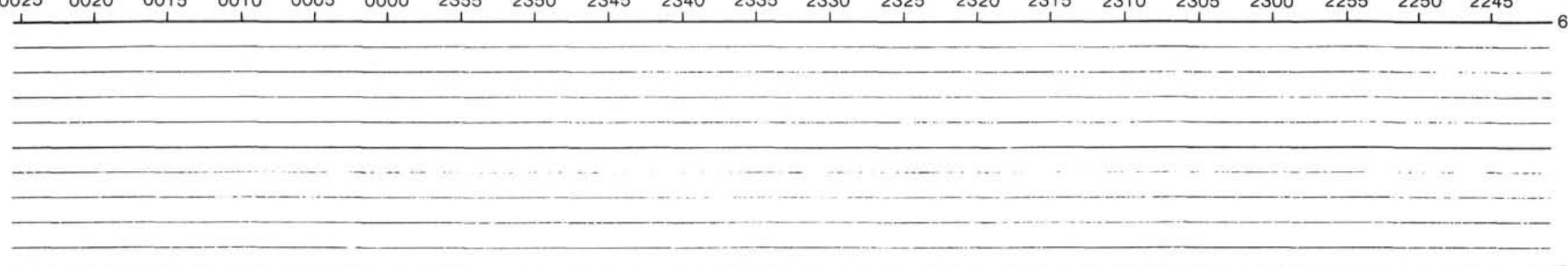

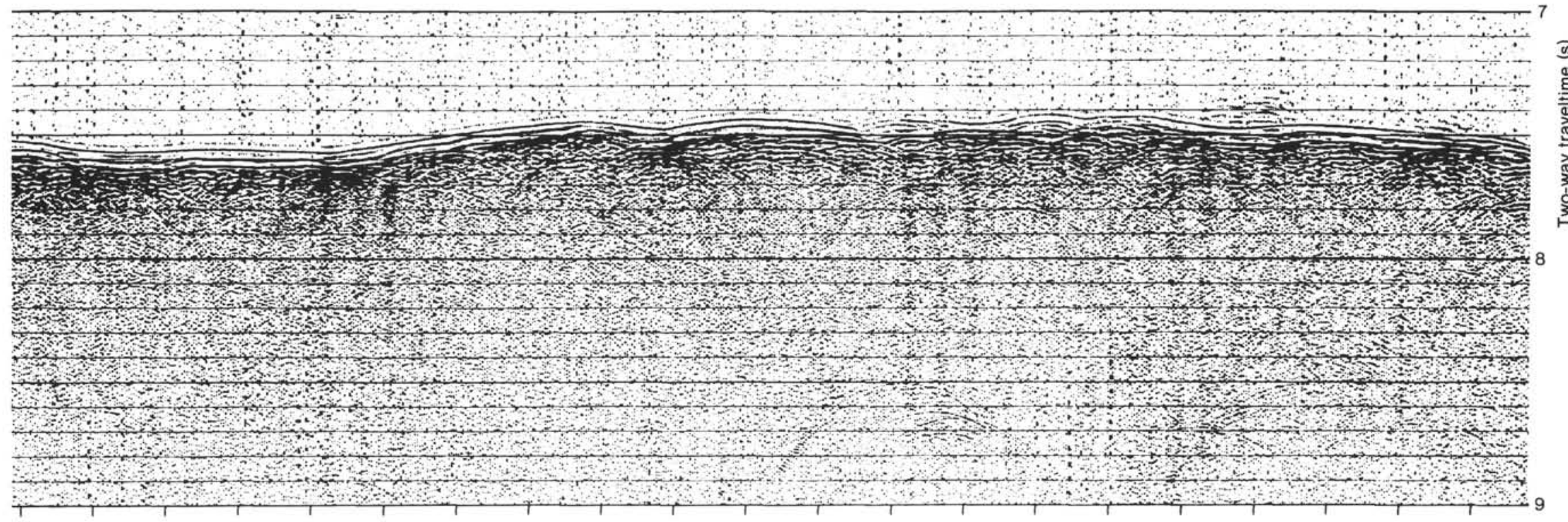

Figure 11. Line 1 (continued) further south of the site. The sediments here appear to be slightly thinner. 


\begin{tabular}{ll}
0 \\
\hline
\end{tabular}

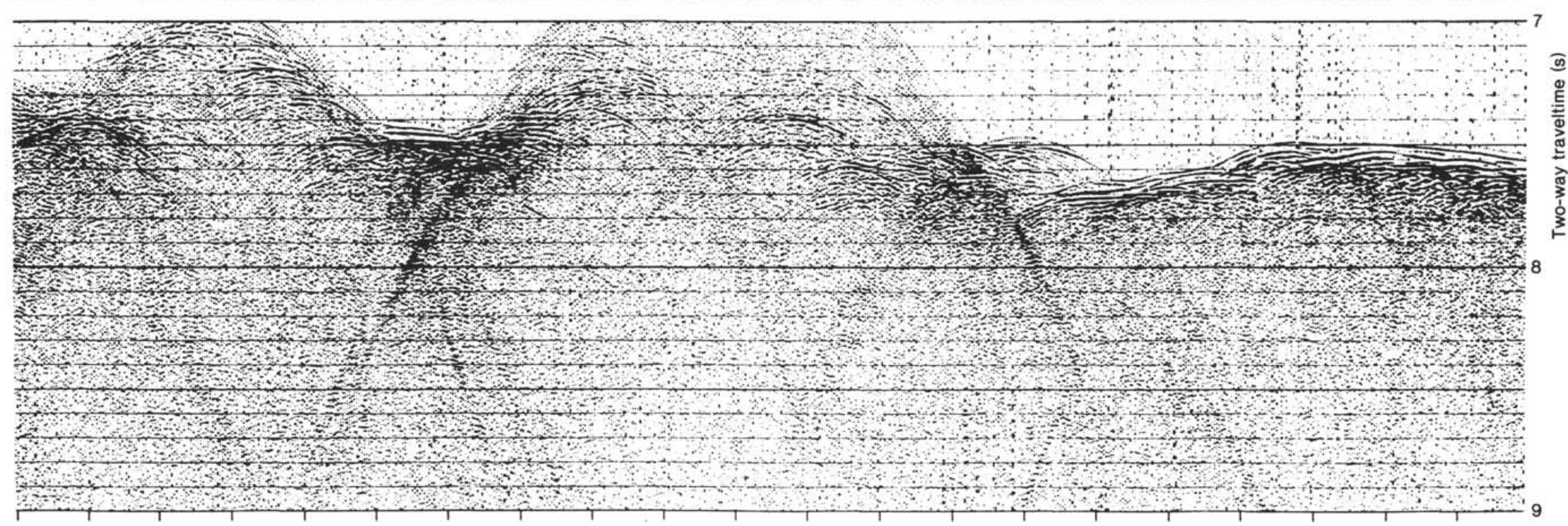

Figure 12. Line 1 (continued). The profile indicates that the topography becomes much rougher further south of the site. 


\begin{tabular}{|c|c|c|c|c|c|c|c|}
\hline$S$ & & & & & & & $\mathrm{~N}$ \\
\hline 230 & 225 & 220 & 215 & 210 & 205 & 200 & 155 \\
\hline
\end{tabular}

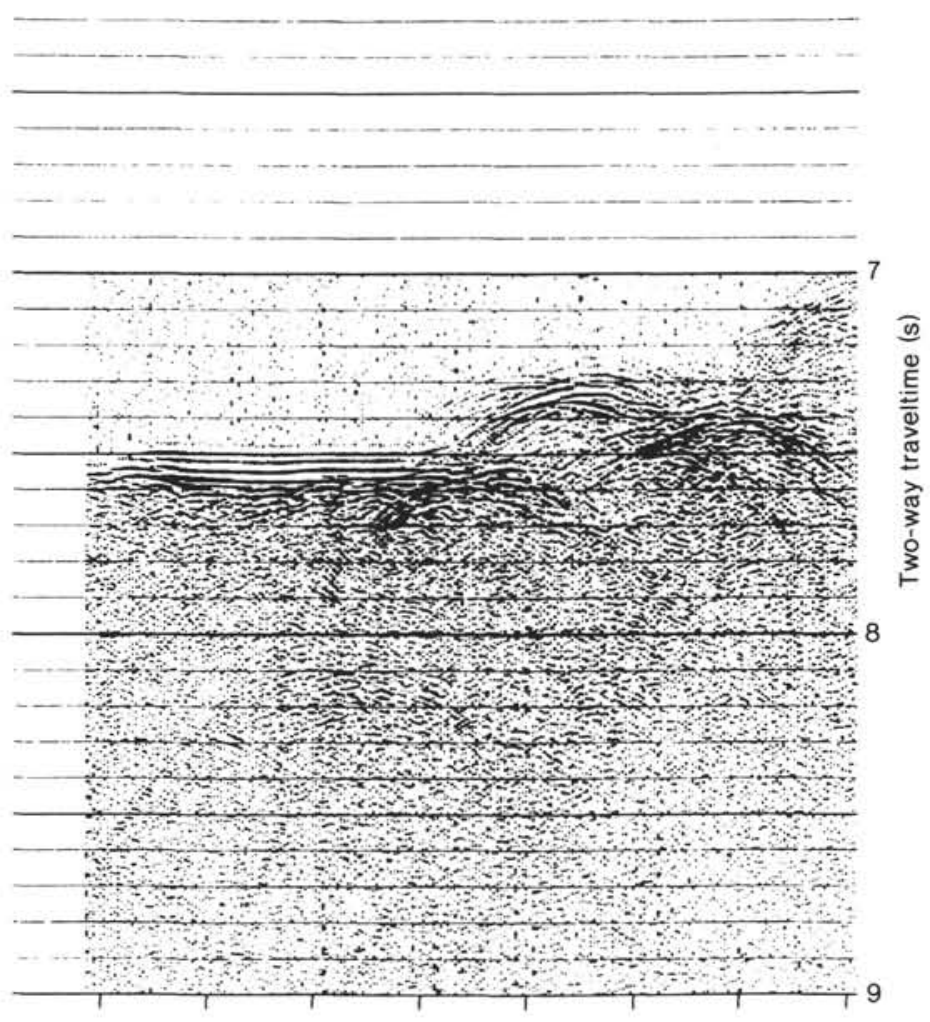

Figure 13. The end of Line 1 of the site survey.

would be resolvable on the $3.5-\mathrm{kHz}$ record. The $3.5-\mathrm{kHz}$ record indicates that these thin chert stringers do not pinch out locally, but are laterally extensive.

\section{REVERBERANT LAYER}

Work done by Houtz and Ludwig (1979) indicated the likely presence of a "reverberant layer" in the seismic profiles for this region. This reverberant layer hypothesis resulted from a series of high-amplitude stratified reflections seen in large volume air-gun data throughout the Southwest Pacific Basin. Houtz and Ludwig explained this phenomenon as reflections from very hard thinlylayered sediments such as those found in calcareous beds and volcanoclastic aprons. They have mapped the extent and thickness of this reverberant layer throughout the Pacific, and, according to their maps, we would have expected to find $60-100 \mathrm{~m}$ of acoustically transparent material followed by $100-120 \mathrm{~m}$ of highly reflective material in the drill hole. No reverberant layer was noticed in the water-gun reflection profiles collected during the site survey. Seventy meters of acoustically transparent sediments were drilled, but below basement was encountered.

Simple one-dimensional synthetic reflection seismograms for the site are shown in Figure 34. A reflection coefficient series derived from the measured core velocities is convolved with far-field air-gun and water-gun wavelets to produce the synthetic profiles. The water-gun pro- file was bandpass filtered from 15 to $125 \mathrm{~Hz}$ to simulate the recording process on board Melville. The air-gun profile was bandpass filtered at lower frequencies of 10 to $40 \mathrm{~Hz}$ to simulate older analog recordings. A stratigraphic interpretation of the synthetic water-gun profile would result in an estimated sediment thickness of $80 \mathrm{~m}$. However, the air-gun profile shows a thick "reverberant layer" below the transparent layer. We agree with Shipley et al. (1983) that the reverberant layer is strictly an instrumentation effect caused by using narrow-band sources (air guns) and receivers. When this air-gun source wavelet reflects off the hard basement reflector, the ringing wavetrain gives the impression of a well-layered stack of high-amplitude sediment reflections.

\section{CONCLUSION}

The site survey conducted immediately prior to the arrival of Glomar Challenger successfully located a site with sufficiently shallow water depth and thick sediment cover to allow setting a reentry cone. The data collected were subsequently correlated with the sediments drilled at the site and the presence of the unexpected chert-bearing sediments provided a satisfactory explanation for the differences between the reflection data gathered on board Melville and Glomar Challenger. What appeared to be a shallow basement reflection on the narrow-band, highfrequency profiles was actually energy reflected off the 


\section{I. KIM ET AL.}

top of chert and porcellanite stringers. The "reverberant layer" of Houtz and Ewing was not observed in the survey data and was not encountered during drilling. The reverberant layer, in this area, appears to be an artifact of the narrow-band analog recording typical of early reflection systems.

\section{ACKNOWLEDGMENTS}

The authors would like to thank Captain Haines and the rest of the crew of the Melville, who helped make the site survey so successful. We are particularly grateful for the efforts of Frank Hubenka, who was responsible for seismic data acquisition and Paul Henkart, who assisted in the seismic data processing. Tom Shipley, Yves Lancelot, and Mark Burnett provided substantial help with their reviews of the manuscript. This research was supported by DARPA Contracts F49620 79-C-0019 and AFOSR-84-0043.

\section{REFERENCES}

French, W. S., and Henson, C. G., 1978. Signature measurements on the water gun marine seismic source. Proc. Offshore Technol. Conf., 2:631-637.
Houtz, R. E., and Ludwig, W. J., 1979. Distribution of reverberant subbottom layers in the southwest Pacific basin. J. Geophys. Res., 84:3497-3504.

Hutchinson, D. R., and Detrick, R. S., 1984. Water gun vs. air gun: a comparison. Mar. Geophys. Res., 6:295-310.

Isacks, B. L, Oliver, J., and Sykes, L. R., 1968. Seismology and the new global tectonics. J. Geophys. Res., 73:5855-5899.

Mammerickx, J., Smith, S. M., Taylor, I. L., and Chase, T. E., 1975. Topography of the South Pacific (map). IMR Tech. Rep. Ser. TR56, Scripps Inst. Oceanogr., La Jolla.

Oliver, J., and Isacks, B. L., 1967. Deep earthquake zones, anomalous structures in the upper mantle, and the lithosphere. J. Geophys. Res., 72:4259-4275.

Robinson, E. A., and Treitel S., 1980. Geophysical Signal Analysis: Englewood Cliffs (Prentice-Hall).

Shipley, T. H., Whitman, J. M., Duennebier, F. K., and Petersen, L. D., 1983. Seismic stratigraphy and sedimentation history of the east Mariana Basin, western Pacific. Earth Planet. Sci. Lett., 64: 257-275.

Date of Initial Receipt: 11 April 1985 Date of Acceptance: 29 January 1986 


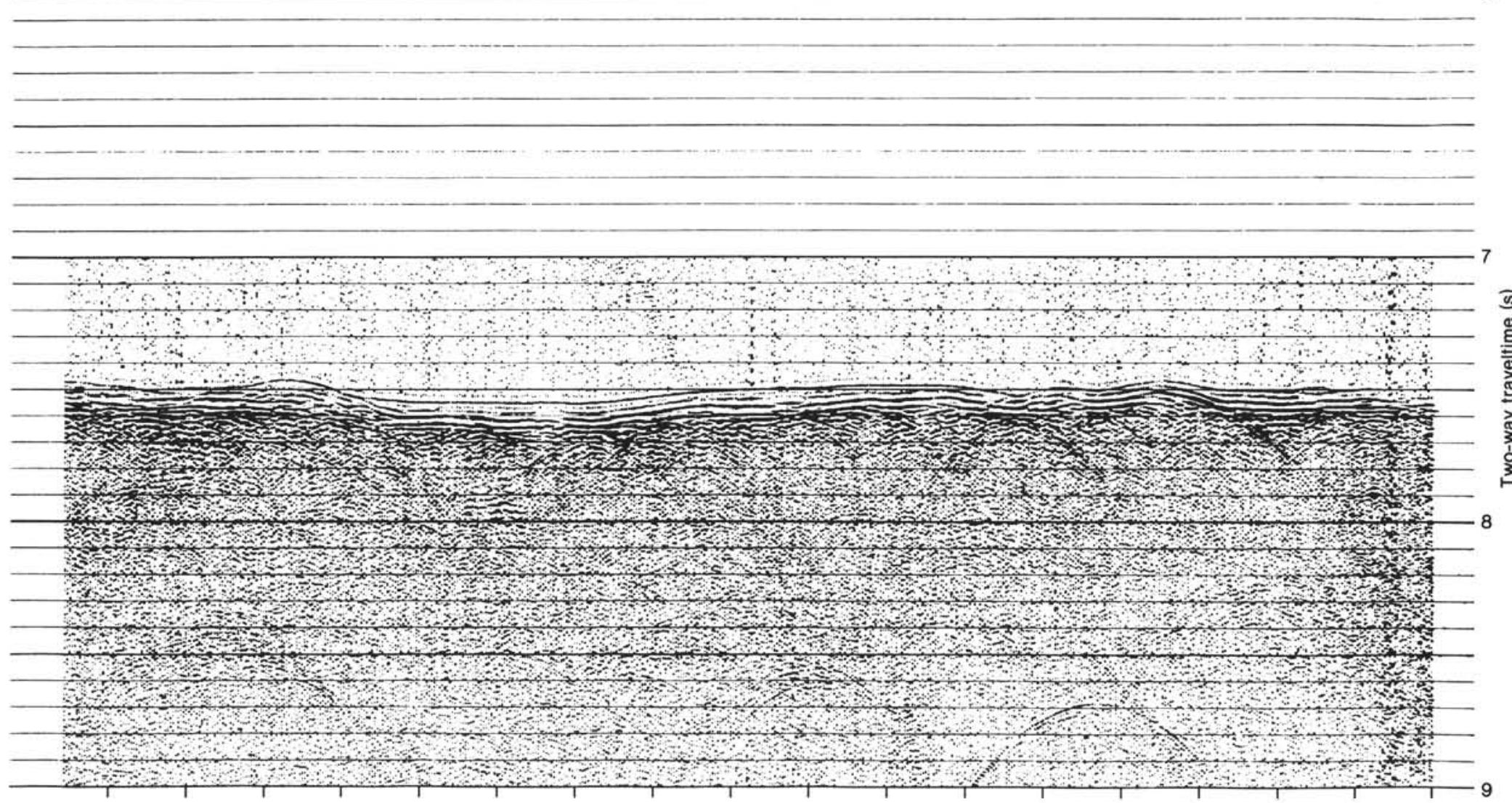

Figure 14. The start of Line 2 as the ship turns to the northeast. Hyperbolic reflections in the basement reflection indicate possible small faults in the upper part of the basalt. 


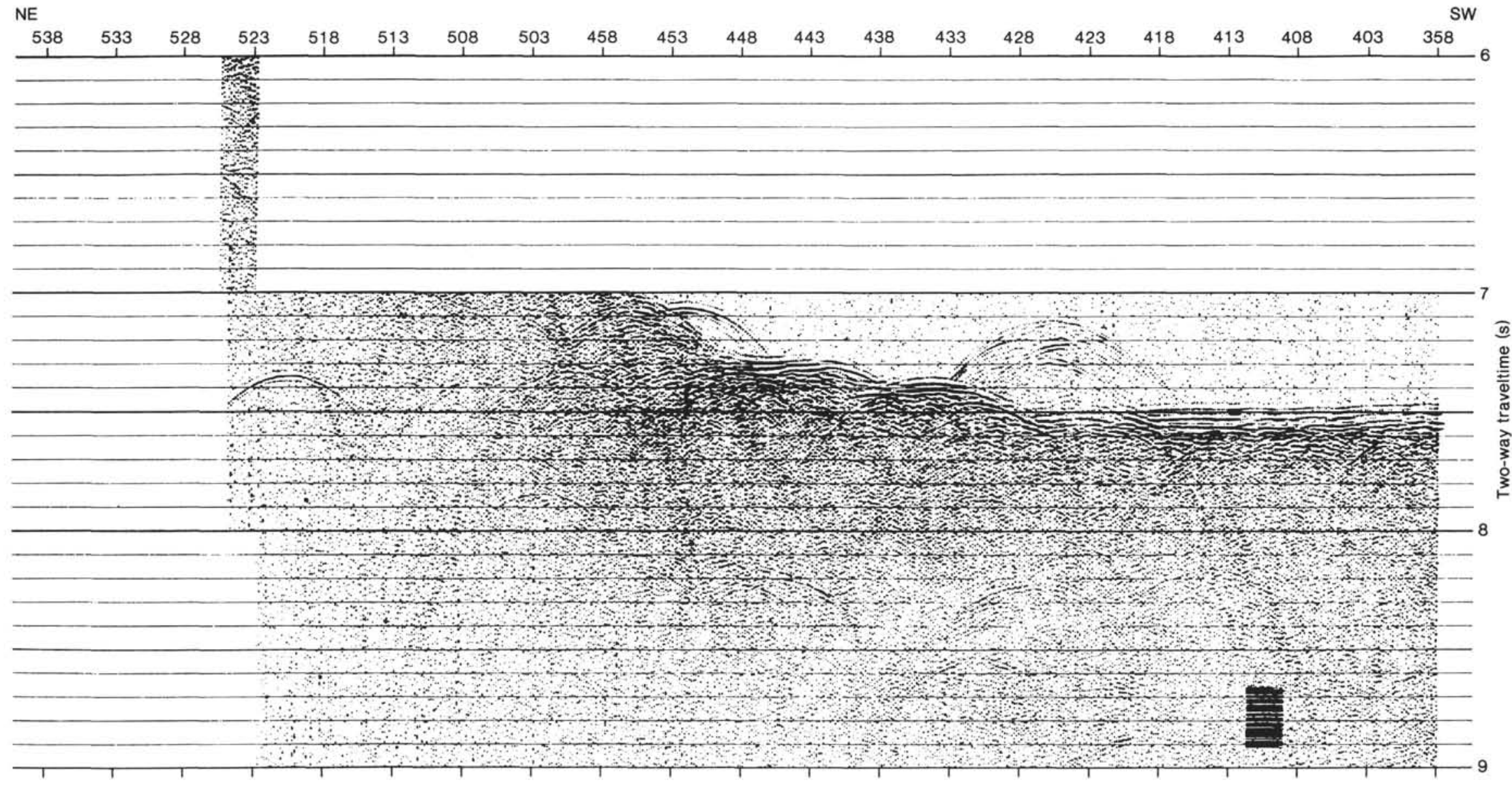

Figure 15. Line 2 (continued) as the ship maneuvers for a perpendicular crossing of the second site. Here the profile goes off scale as the delay switches were not adjusted quickly enough. 

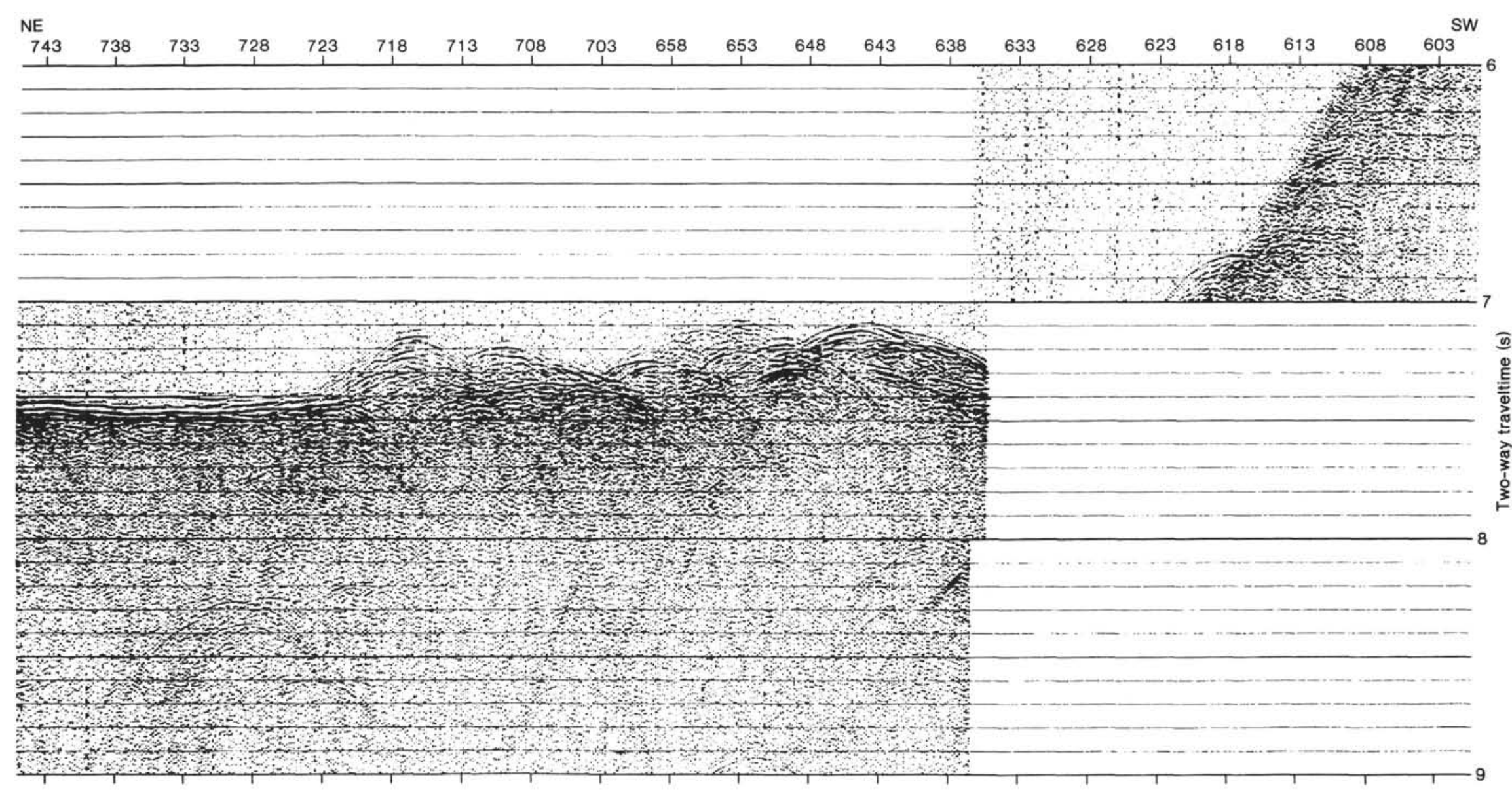

Figure 16. Line 2 (continued) as the ship comes off the large bathymetric high back into the flatter area. 



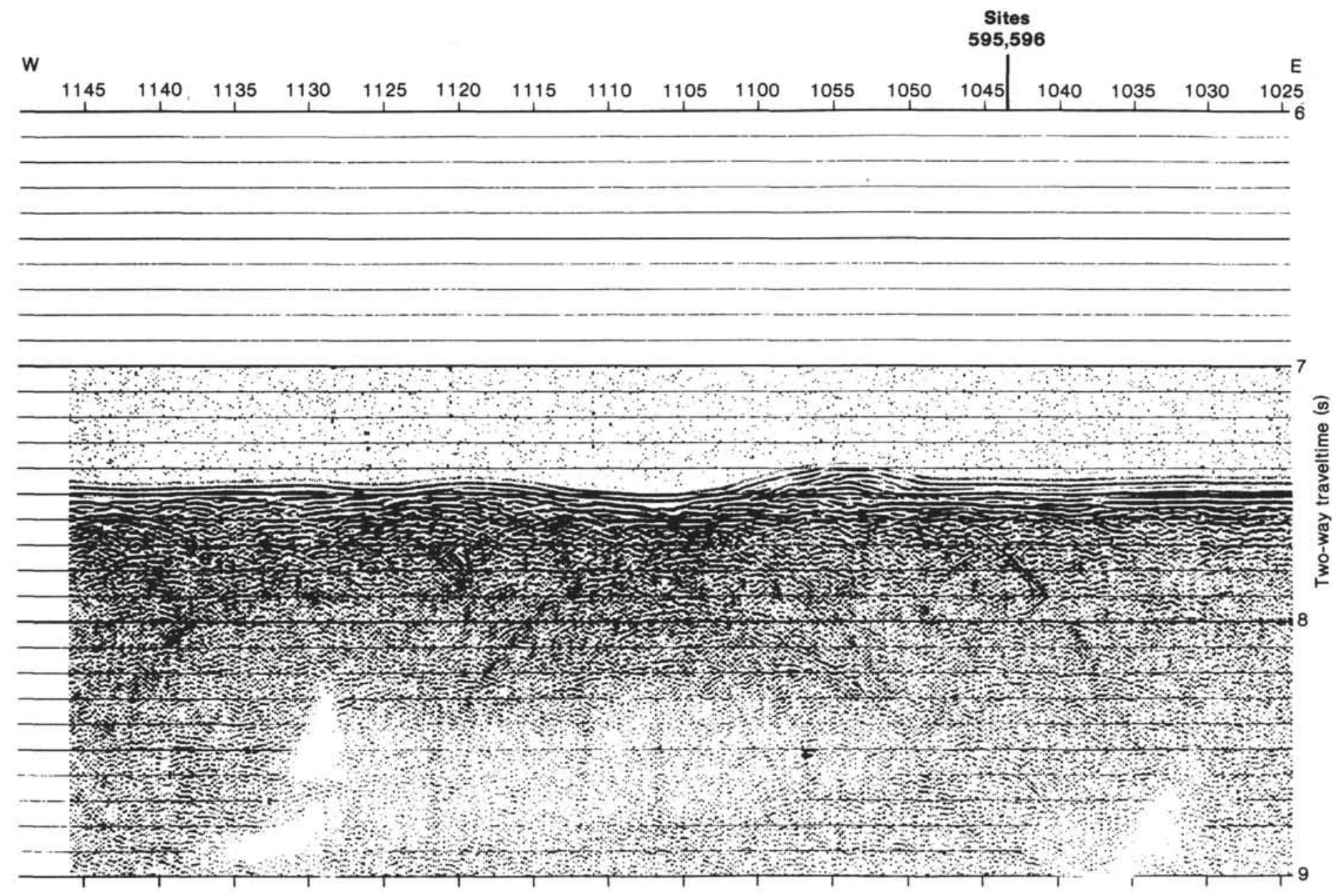

Figure 19. The end of Line 3. This profile shows a perpendicular crossing through the site. A mound is evident near the site. This mound was not seen in Line 1. The sediments also appear to be thickest around this mound. 


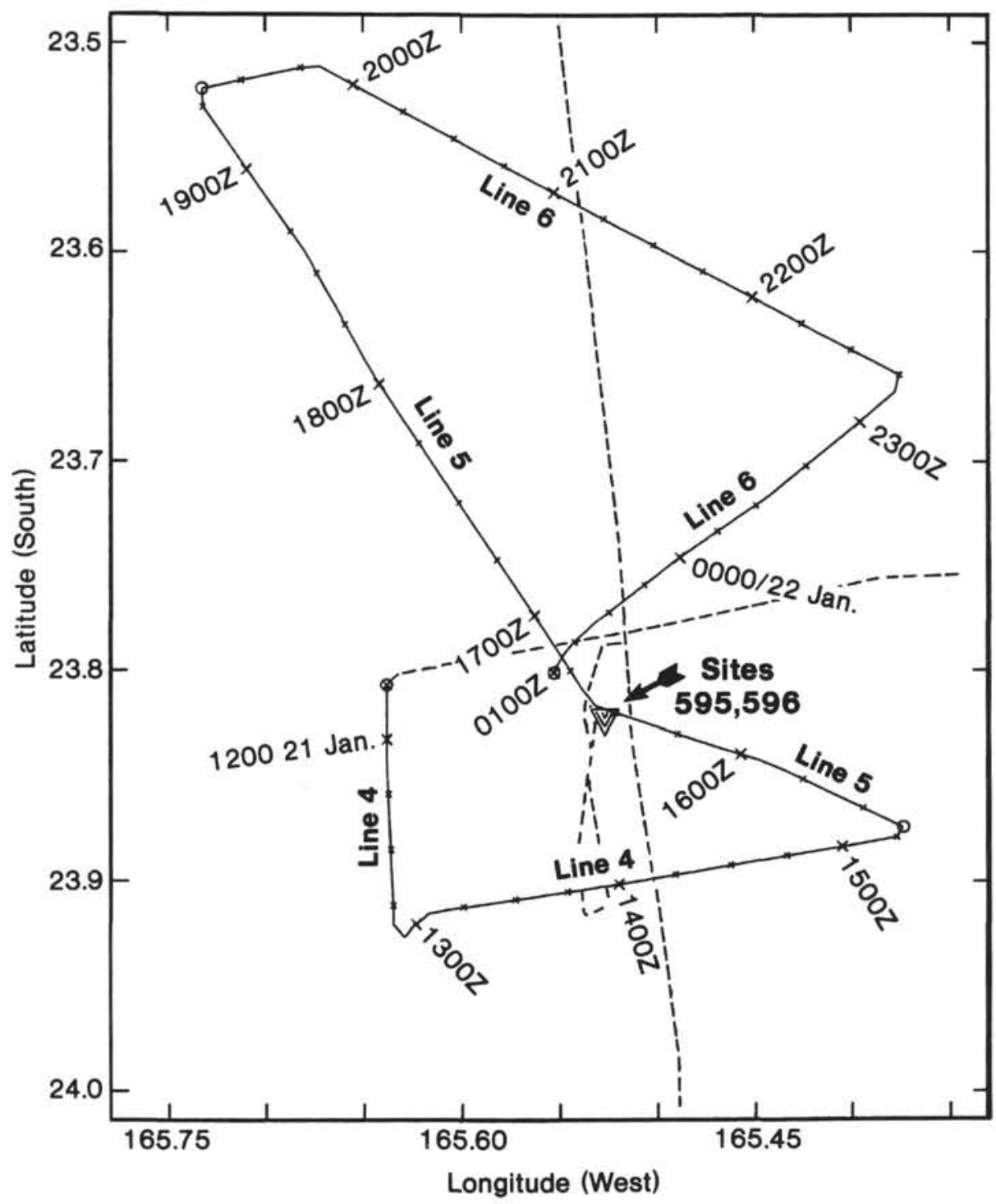

Figure 20. Location of site survey reflection Lines 4-6. Filled triangle indicates the drill site. Parts of the rest of the survey are denoted by the dashed lines. 
E

w/s

N

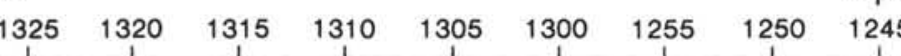

$\begin{array}{llll}1240 & 1235 & 1230 \quad 1225\end{array}$

1220

$1215 \quad 1210 \quad 1205$

1200

1155

1150

145

\begin{tabular}{l}
\hline \\
\hline
\end{tabular}

-

-

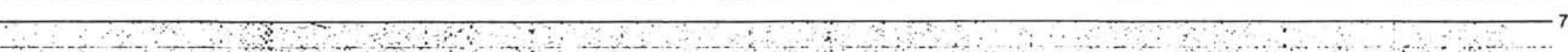
-

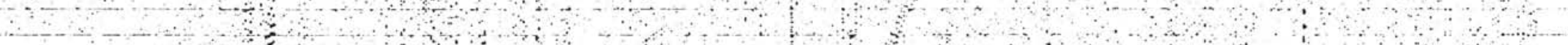

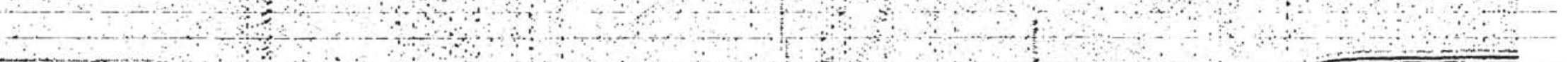

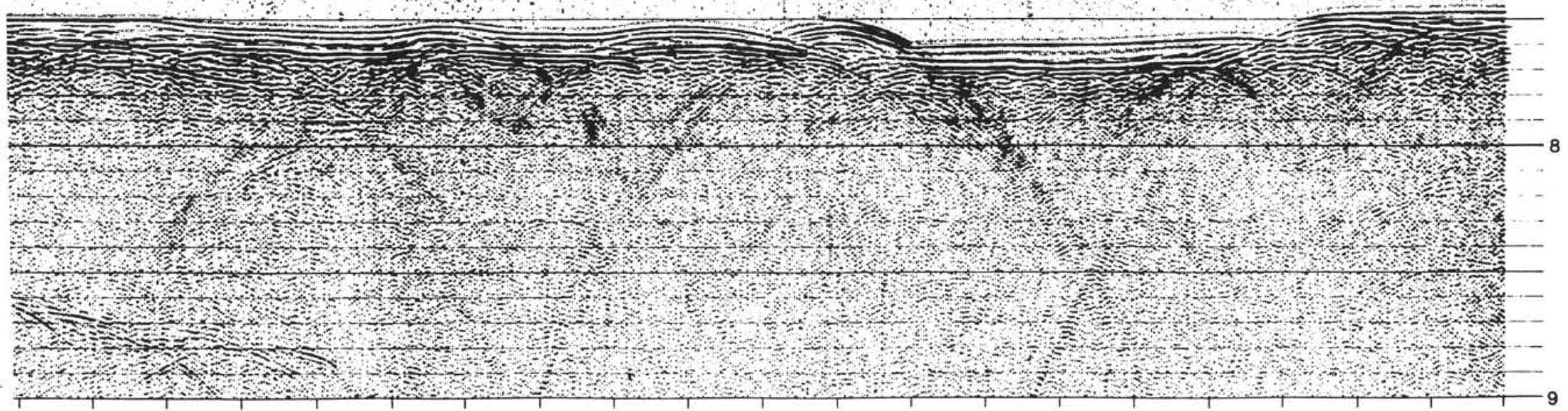

Figure 21 . The start of Line 4 of the water-gun site survey to investigate the sediments slightly south of the site. Deep reflections at $8.8 \mathrm{~s}$ from $1305 \mathrm{Z}$ to $1325 \mathrm{Z}$ are most likely an out-of-plane reflection. 
E

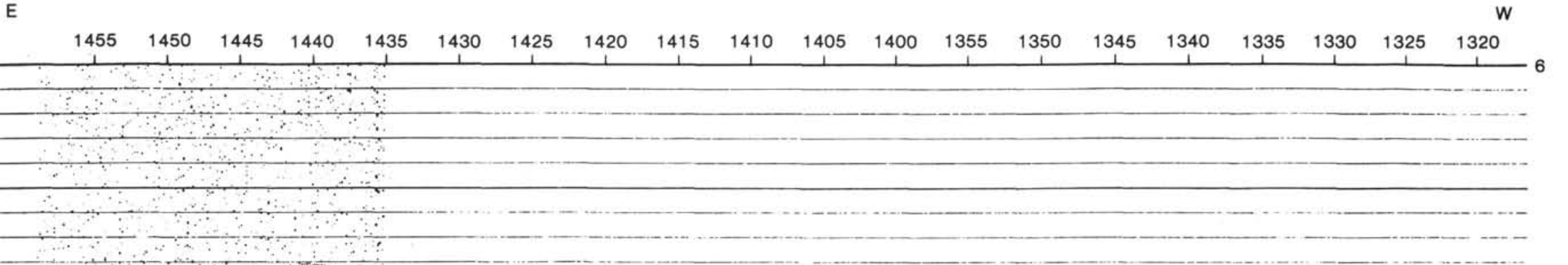

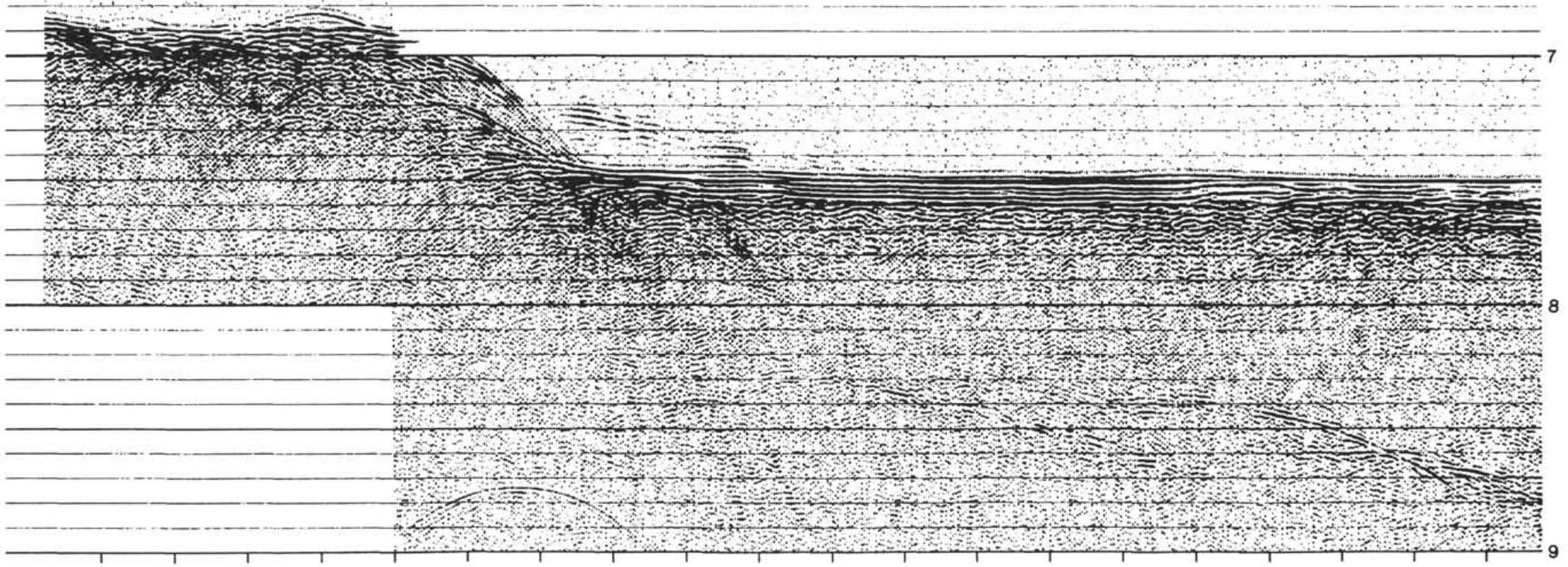

Figure 22. Line 4 (continued). As the ship moved further east, the bathymetry became rougher so the ship turned back to the northwest. The out-of-plane reflection seen in Figure 20 continues at about $8.5 \mathrm{~s}$ from $1320 \mathrm{Z}$ to $1400 \mathrm{Z}$. 
NW

SE

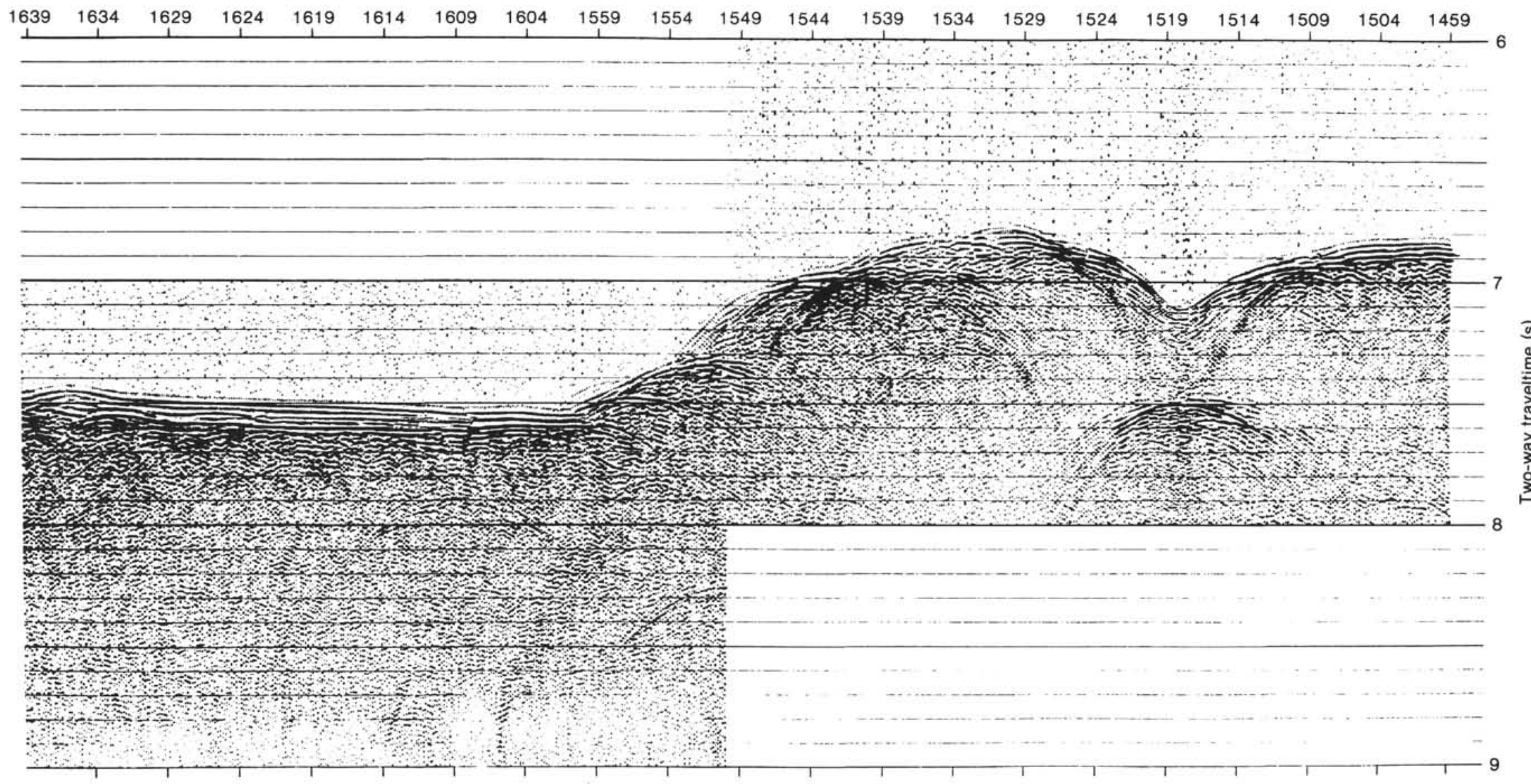

Figure 23. The start of Line 5 of the reflection site survey. Here the ship comes off the bathymetric high and back into the flatter topography. 


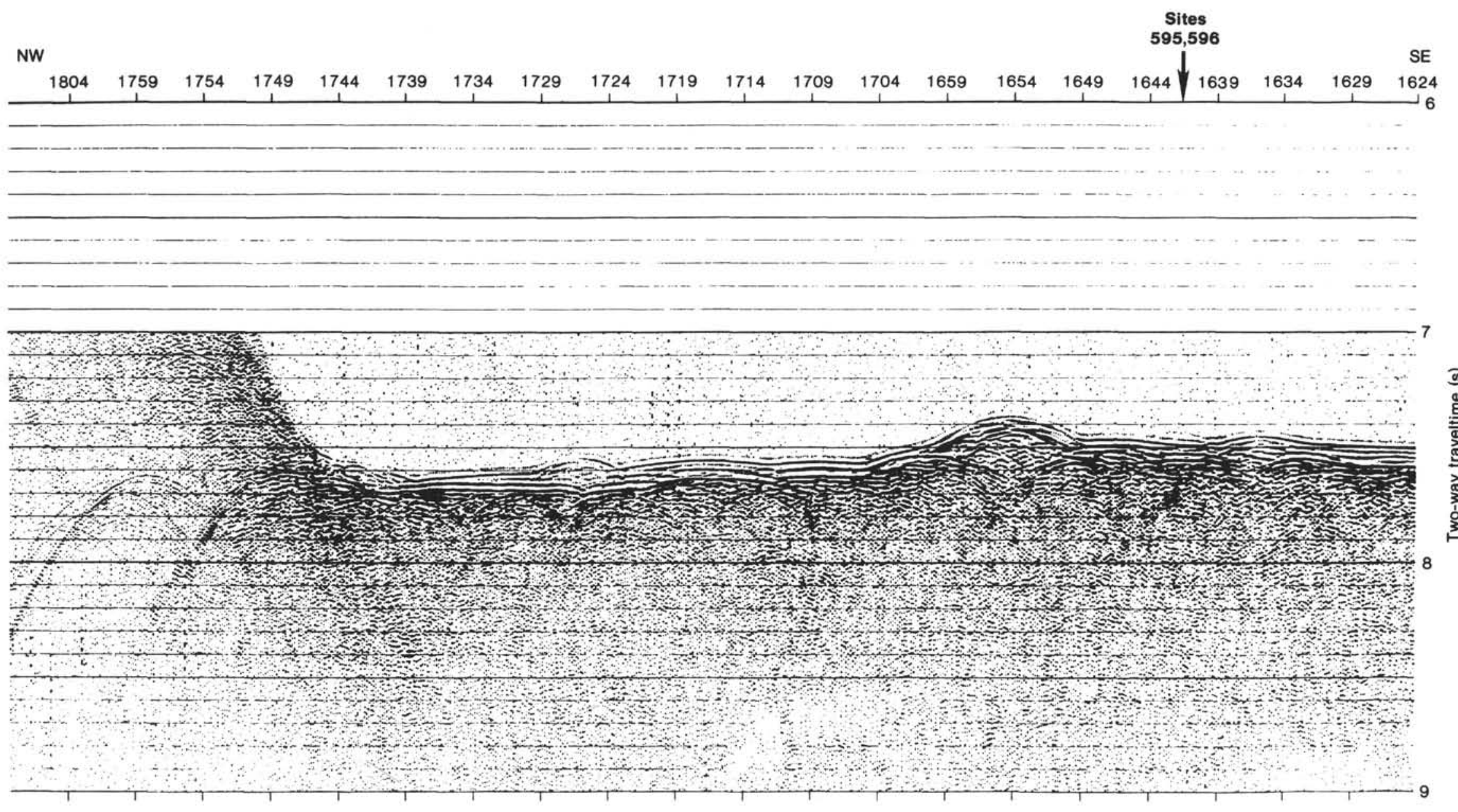

Figure 24. Line 5 (continued) as the ship passes through the site in a northwest direction. Again the mound seen in Line 3 (Figure 19) is evident. Higher bathymetry is seen northwest of the site. 
NW

SE

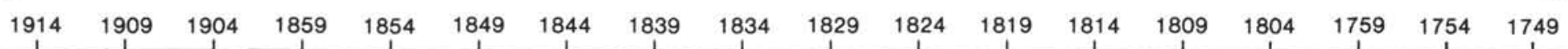

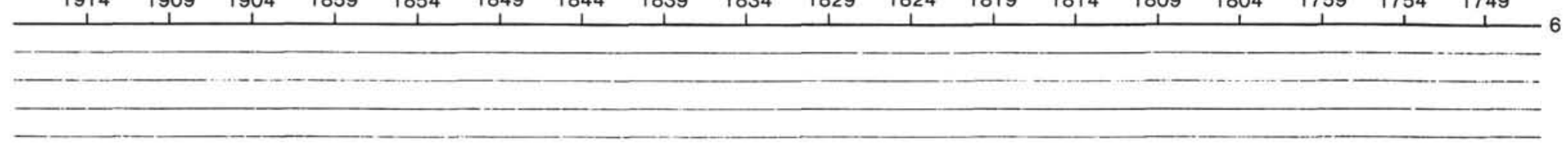

\begin{tabular}{l}
\hline \\
-
\end{tabular}

-

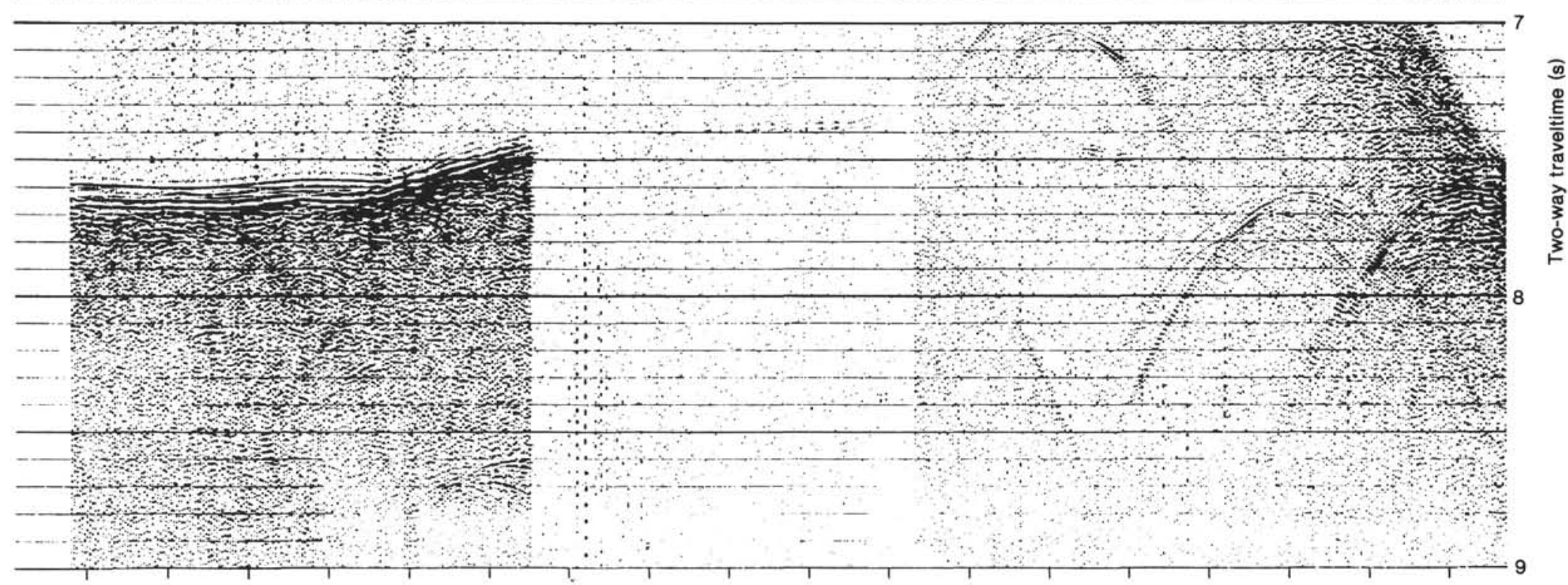

Figure 25 . End of Line 5 as the ship passes back down into a flatter area. Data loss from $1749 \mathrm{Z}$ to $1823 \mathrm{Z}$ is a result of incorrect delay setting and data loss from $1823 \mathrm{Z}$ to $1848 \mathrm{Z}$ is due to recording failure. At the end of Line 5, the ship turned back to survey north of the site. 


.

-

2. -

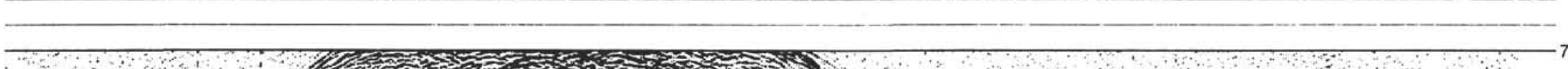

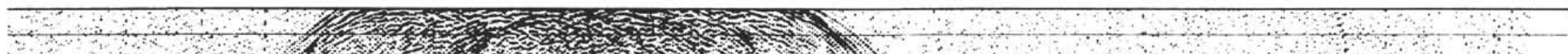
(1) Non

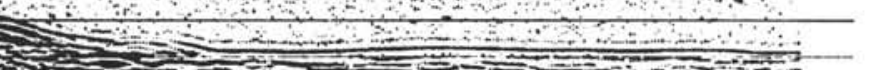
N W

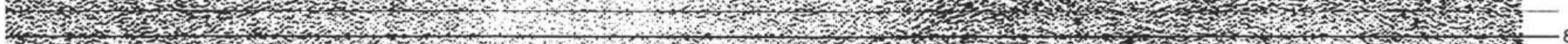

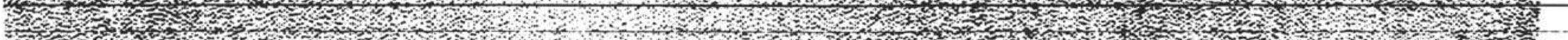
H

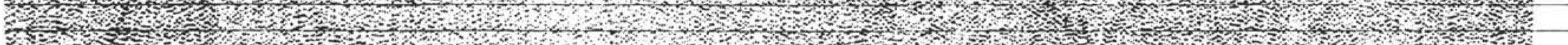

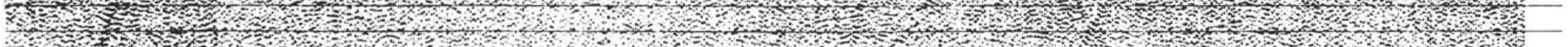

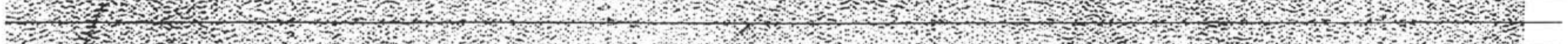
T.

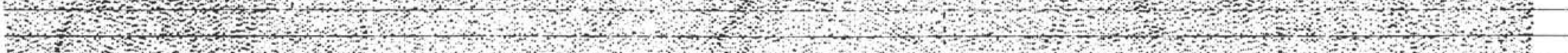

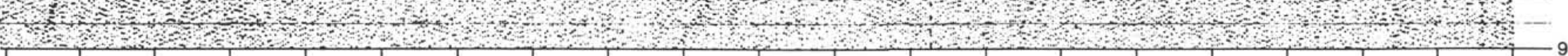

Figure 26. The start of site survey Line 6. Melville first started east and then turned to the southeast. 


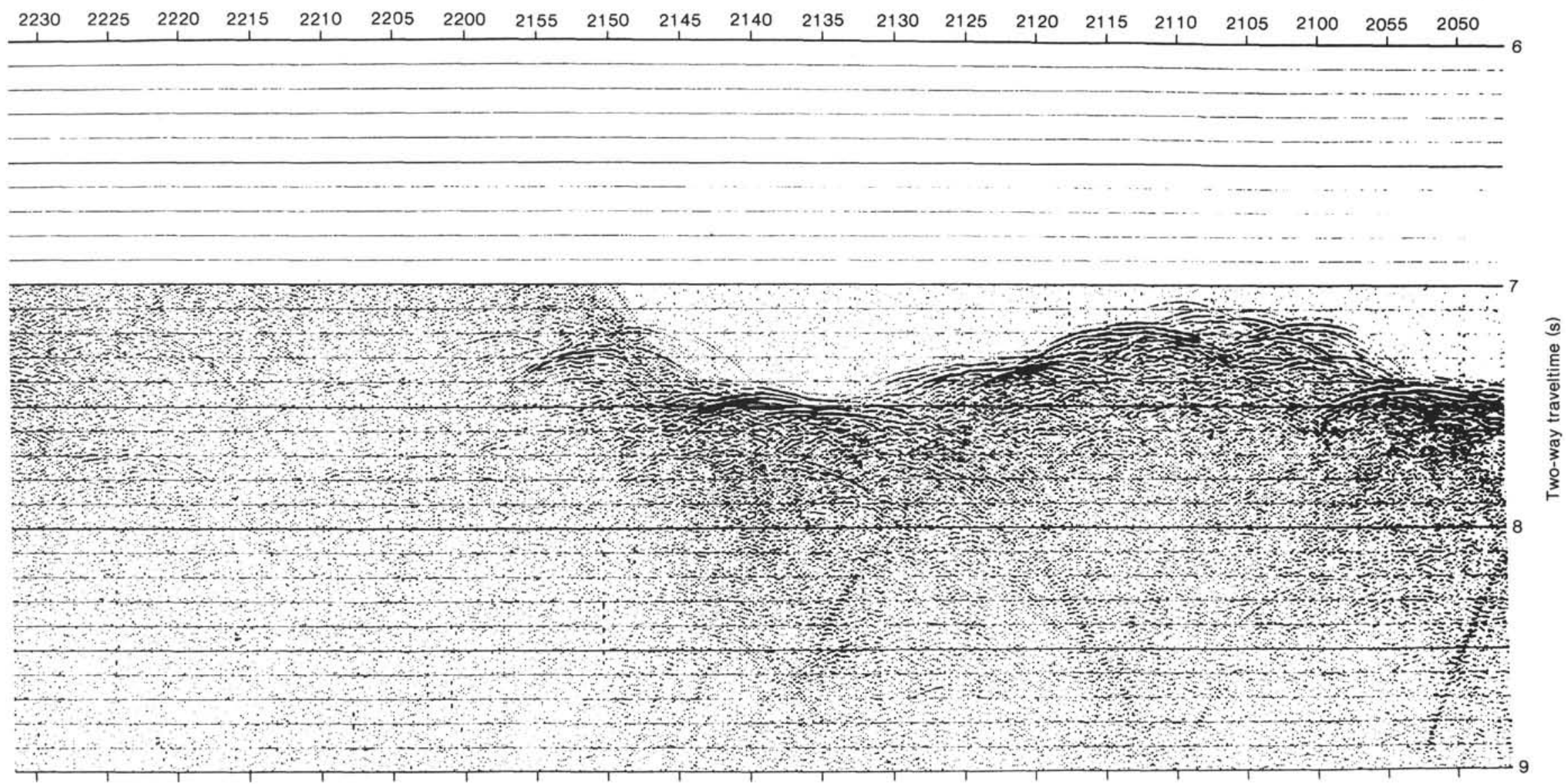

Figure 27. Line 6 (continued). Rougher topography was encountered in this portion of the survey. 


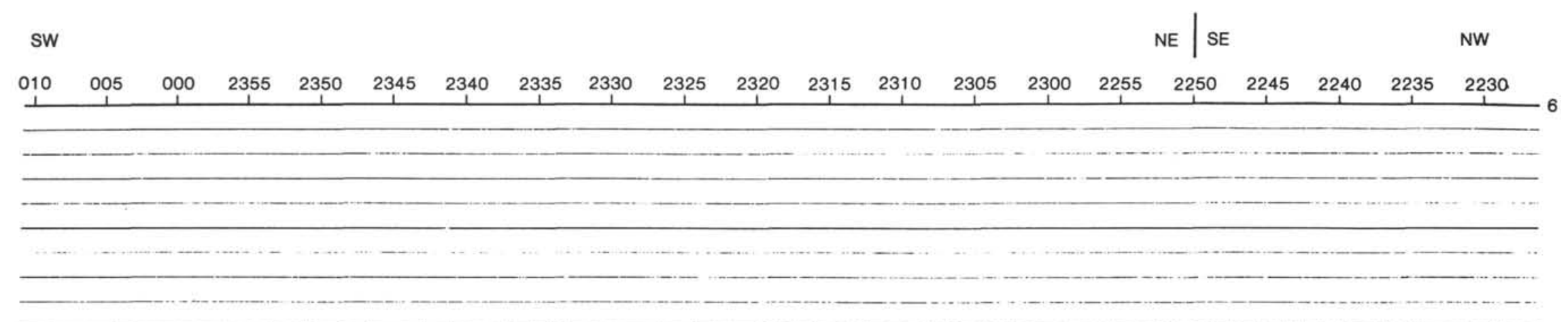

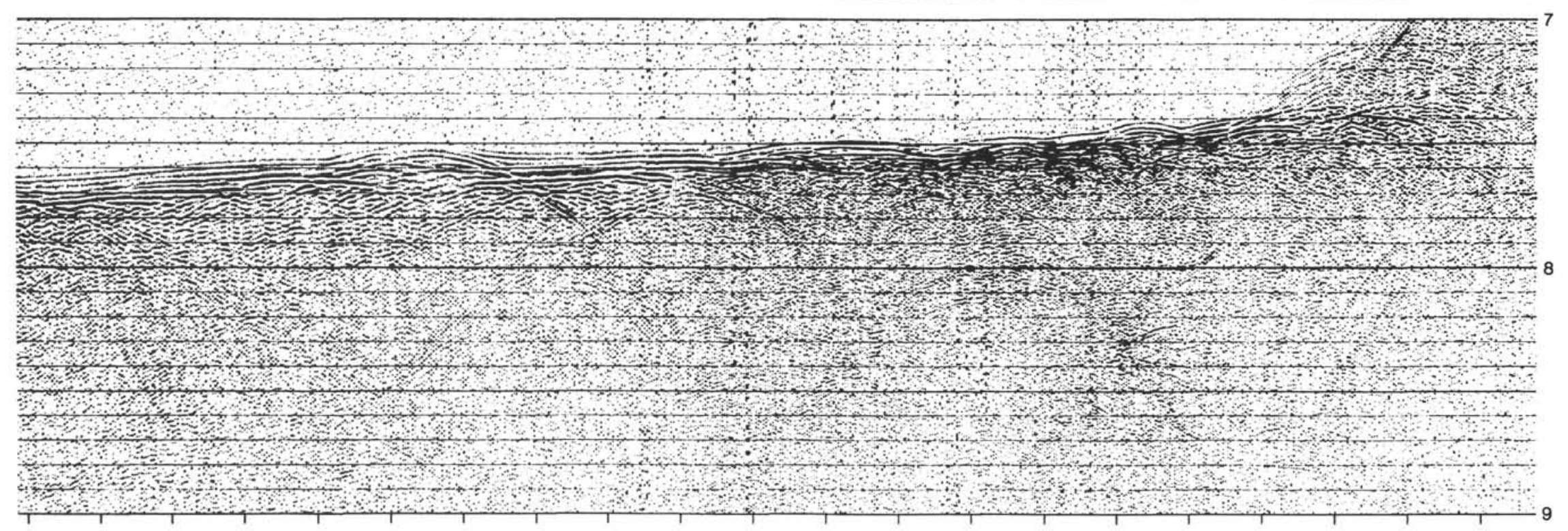

Figure 28. Line 6 (continued). The ship turned back towards the site since no area of greater sediment thickness was found north and east of the site. The sediments appear to thicken slightly as the ship moved southeast. 


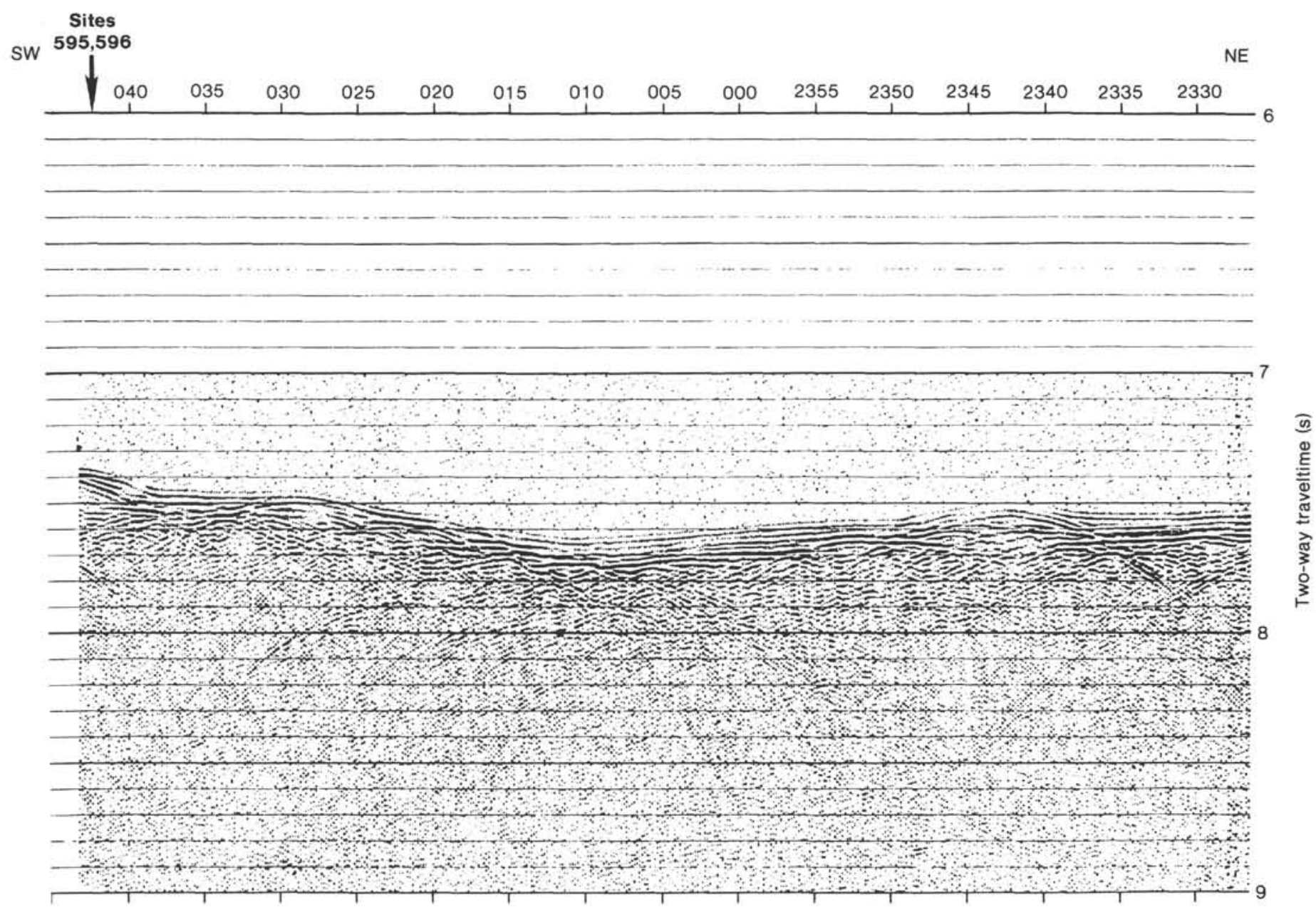

Figure 29. The end of Line 6 as Melville approached the site from the northeast. 


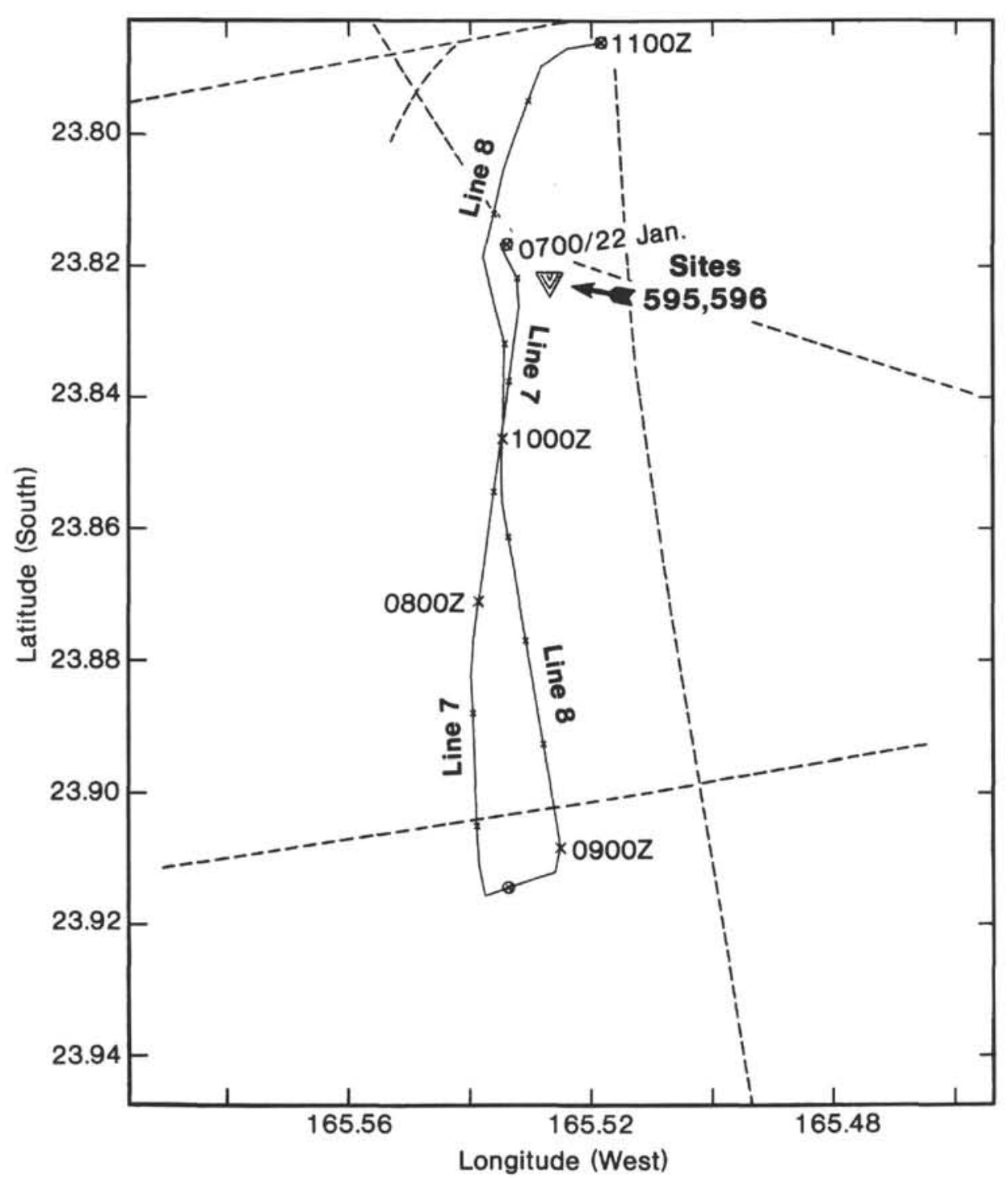

Figure 30. Location of site survey Lines 7 and 8 immediately below the site (located by the filled triangle). Dashed lines show additional profiles. 


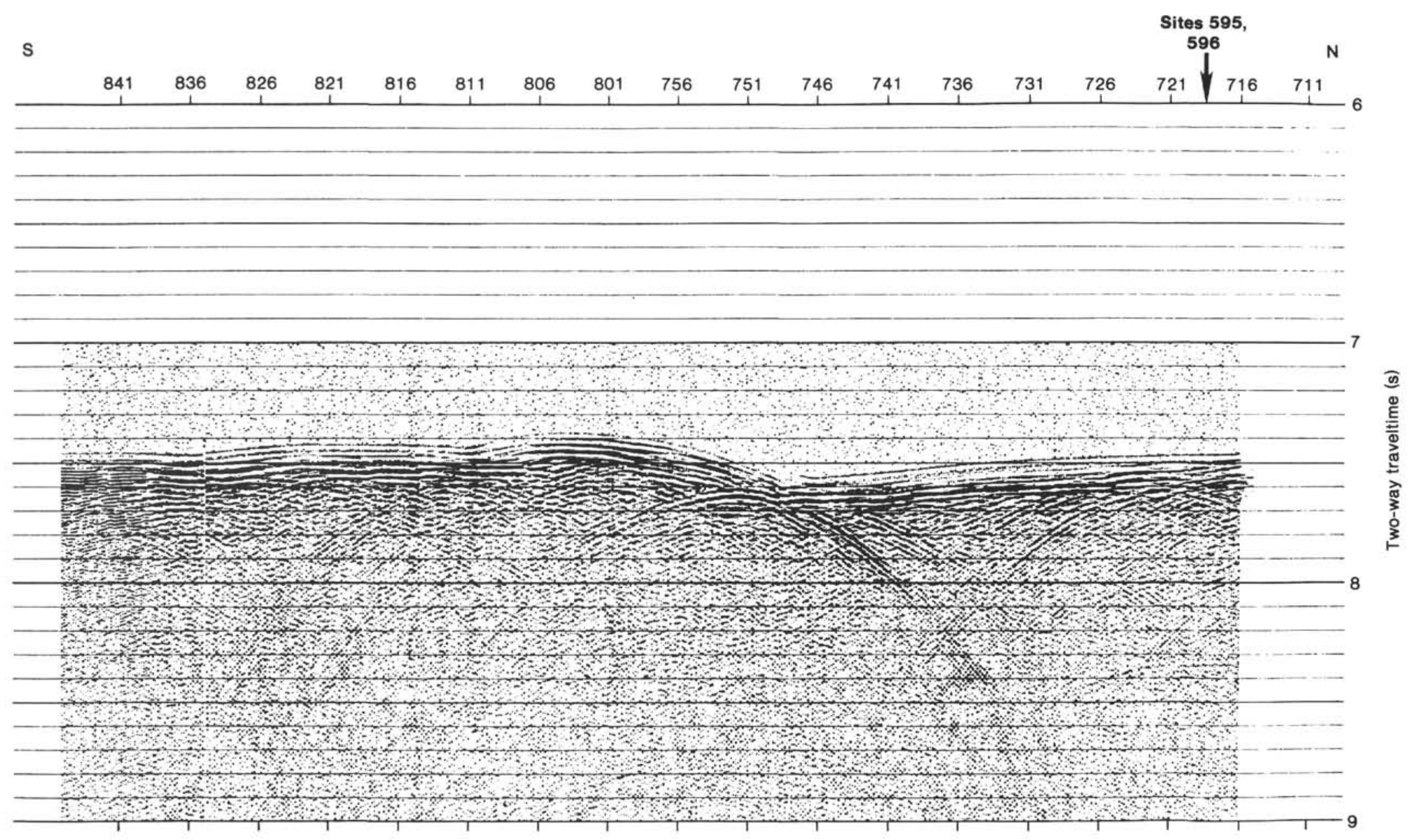

Figure 31. Line 7. The ship traveled due south of the drilling site. 
Sites

$\begin{array}{llllllllllllllllllllll}1030 & 1025 & 1020 & 1015 & 1010 & 1005 & 1000 & 955 & 950 & 945 & 940 & 935 & 930 & 925 & 920 & 915 & 910 & 905 & 900 & 855 & 850 & 1\end{array}$

\begin{tabular}{llll}
\hline 1 & 1 & \\
\hline
\end{tabular}

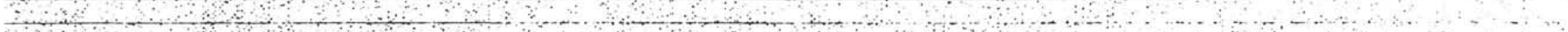

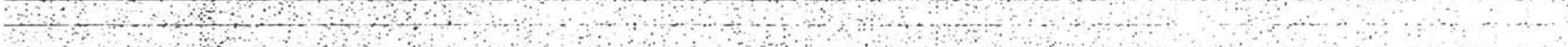

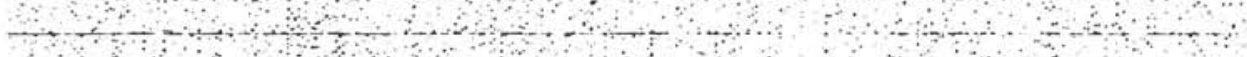

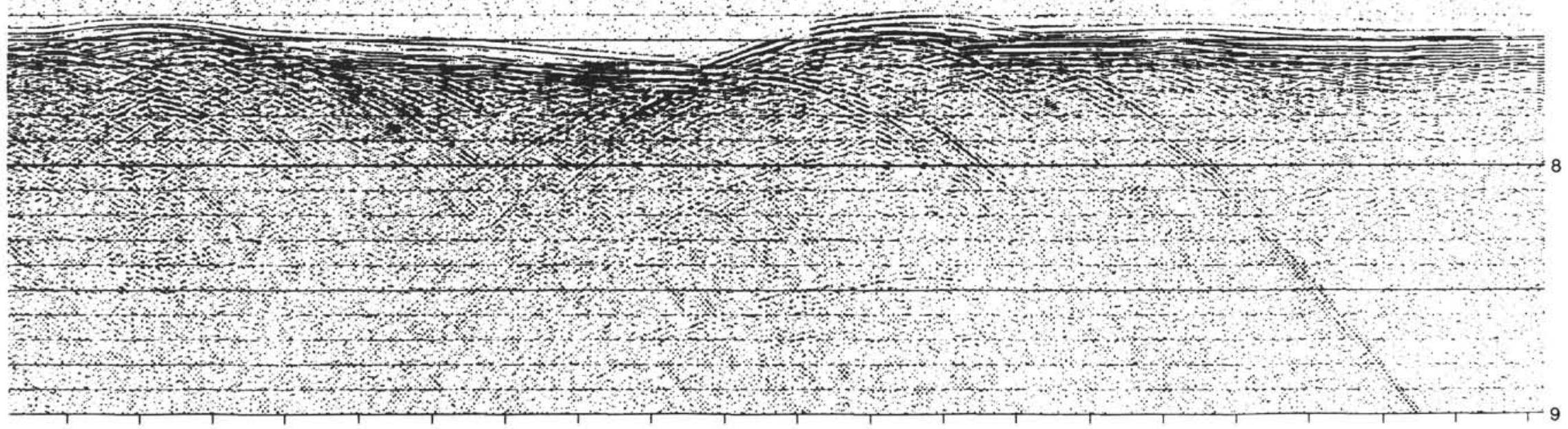

Figure 32. Line 8. This line parallels Line 7 as Melville returned to the site to terminate the site survey. 


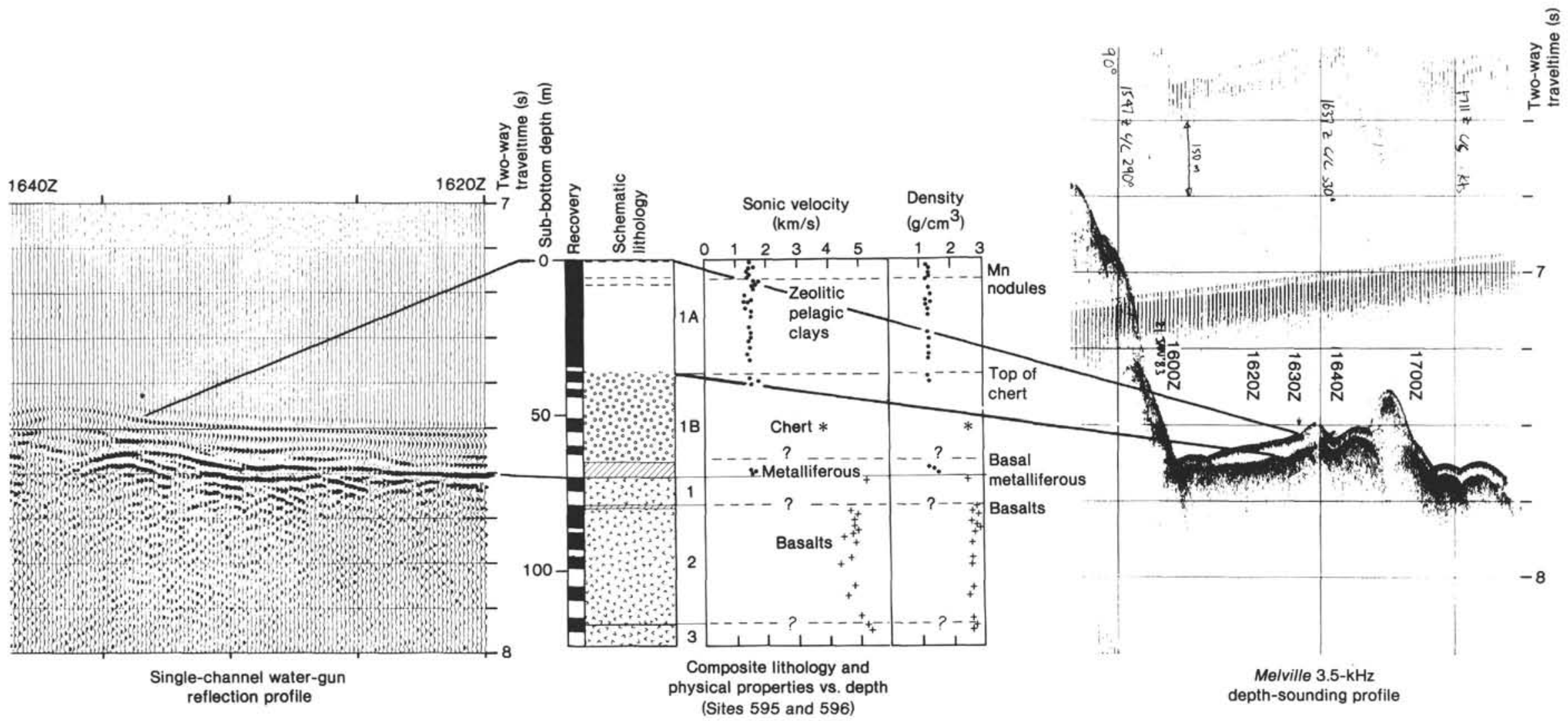

Figure 33. Correlation of physical properties and sediment lithology with water-gun reflection data and 3.5-kHz sounding data. Reflections off the chert layer and the top of oceanic crust are seen in the reflection data, but only the chert reflection is seen in the $3.5-\mathrm{kHz}$ data. 


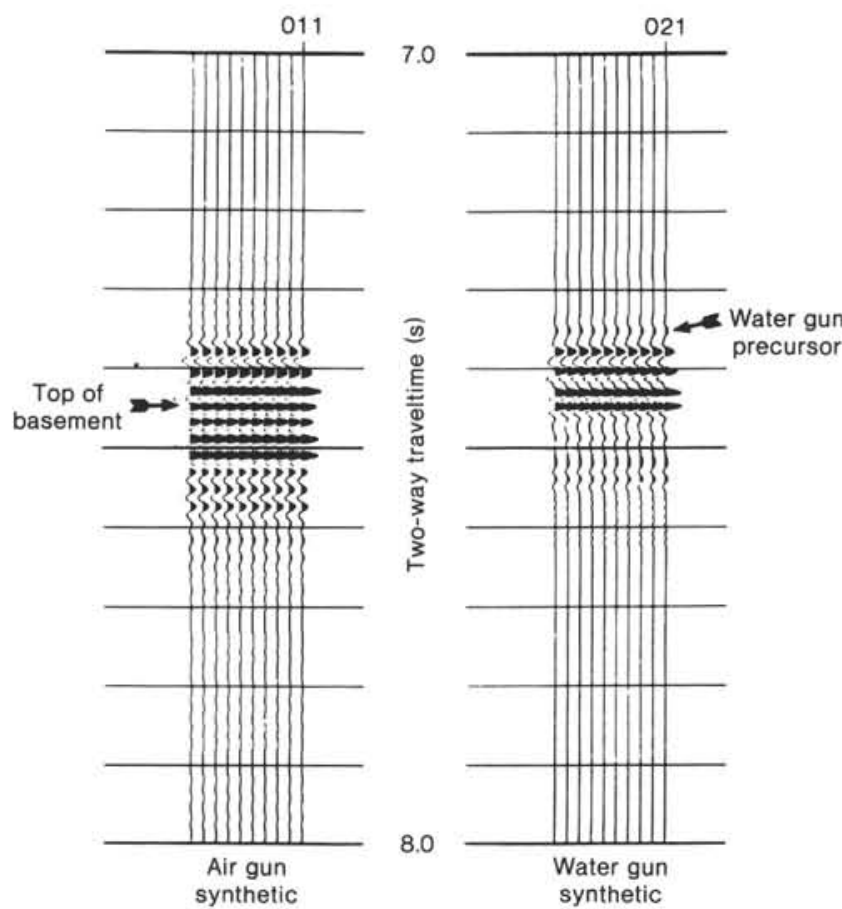

Figure 34. Synthetic seismograms using water-gun and air-gun sources to show the possible misinterpretation of a "reverberant layer" in narrow band air-gun profiles. The same reflection coefficient series was used in both synthetic seismograms. However, since an airgun is a narrow-band source, a single reflection off of an interface (the basement in this case) appears as a series of well-layered reflectors. 